\title{
Taxonomic revision of the deep channel electric fish genus Sternarchella (Teleostei: Gymnotiformes: Apteronotidae), with descriptions of two new species
}

\author{
Kory M. Evans ${ }^{1}$, William G. R. Crampton ${ }^{2}$, James S. Albert ${ }^{1}$
}

This paper provides a taxonomic revision of the Neotropical electric fish genus Sternarchella, with redescriptions of seven valid species and descriptions of two new species. A maximum parsimony analysis of 76 morphological characters from seven ingroup and seven outgroup taxa recovered a non-monophyletic Sternarchella, in which a clade comprising two species with a ventral mouth $(S$. orinoco $+S$. sima) is the sister group to a clade comprising seven species that possess a terminal or superior mouth. Nested within this higher-diversity clade is the genus Magosternarchus (recognized herein as a junior synonym of Sternarchella) comprising M. duccis and M. raptor. The Magosternarchus clade forms a polytomy with S. orthos and S. schotti. Sternarchella calhamazon + a new species from the upper Río Madeira (sister species to S. calhamazon), and a new larger-bodied species from the central and upper Río Amazonas also form a clade. Sternarchella orthos is distributed in both the Amazon and Orinoco basins, where it exhibits considerable phenotypic diversity. Sternarchella orthos includes most specimens from the Amazon formerly assigned to the nominal species $S$. terminalis (recognized herein as a junior synonym of $S$. schotti).

Keywords: Amazon, Evolution, Geometric morphometrics, Identification key, Magosternarchus.

Este artigo propõe uma revisão taxonômica do gênero Neotropical de peixe-elétrico Sternarchella, incluindo a redescrição de sete espécies válidas e duas novas espécies. Análise de máxima parcimônia com 76 caracteres morfológicos e amostragem de sete grupos internos e sete grupos externos indica que Sternarchella não constitui grupo monofilético, sendo um clado composto por duas espécies com bocas ventrais $(S$. orinoco $+S$. sima) e outro com sete espécies com bocas terminais ou superiores. Dentro deste último clado estão as espécies do gênero Magosternarchus (reconhecido aqui como um sinônimo júnior de Sternarchella): M. duccis e M. raptor. O clado de Magosternarchus forma uma politomia com S. orthos e S. schotti. Sternarchella calhamazon + uma nova espécie do alto rio Madeira (espécie irmã de S. calhamazon) e uma nova espécie de corpo maior do rio Amazonas central e superior também formam um clado. Sternarchella orthos está distribuída nos rios amazônicos e no Orinoco, onde apresenta elevada diversidade fenotípica. Sternarchella orthos inclui a maioria dos espécimes do rio Amazonas anteriormente atribuídos à S. terminalis (considerada neste estudo como sinônimo júnior de S. schotti).

Palavras-chave: Amazônia, Chave de identificação, Evolução, Magosternarchus, Morfometria geométrica.

\section{Introduction}

The genus Sternarchella Eigenmann (1905), known as bulldog knife-fishes in the aquarium trade, is a clade of apteronotid electric fishes with seven valid species currently recognized (Ferraris et al., 2017) distributed in the lowlands of the Amazon and Orinoco basins (Tab. 1). Most of these species (S. calhamazon, S. duccis, S. orthos, S. raptor, $S$. schotti and $S$. sima) inhabit the deep $(10-50 \mathrm{~m})$ channels of the Amazon River and some of its larger tributaries, and one species $(S$. orinoco) is restricted to large rivers channels in the Orinoco basin. As with other gymnotiform fishes,
Sternarchella species generate weak (mv) electric organ discharges (EODs) for use in navigation and communication (Crampton, Albert, 2006). Sternarchella species are notable in generating very high frequency EODs ranging from 772 to 2,180 cycles per second, making them the fastest known biological oscillators on Earth (Albert, Crampton, 2005).

Species of Sternarchella and other members of the clade Navajini exhibit a specialized suite of traits associated with life in deep and swiftly flowing river channels, including reduced eyes, pigmentation, and ossification (Albert, 2001). The genus exhibits one of the fastest rates of skull shape evolution among gymnotiforms (Evans et al., 2017a).

\footnotetext{
${ }^{1}$ Department of Biology, University of Louisiana at Lafayette, P.O. Box 42451, Lafayette, LA 70504, USA. (KME) kxe9300@louisiana.edu, (JSA) jalbert@louisiana.edu (corresponding author)

${ }^{2}$ Department of Biology, University of Central Florida, P.O. Box 162368. Orlando, FL, 32816, U.S.A. crampton@ucf.edu
} 
Sternarchella also exhibits diversity in mouth position, presumably associated with trophic ecology, ranging from a sub-terminal gape in $S$. orinoco and S. sima, to a terminal gape in $S$. orthos and $S$. schotti, and a superior gape in $S$. calhamazon (Evans et al., 2017b). This diversity in mouth position may correlate with trophic habits, with sub terminalmouthed species feeding on benthic invertebrates, and terminal- and superior-mouthed species feeding primarily on fishes higher in the water column (K. M. Evans, pers. obs.).

The genus Sternarchella was erected in Eigenmann, Ward (1905) to include S. schotti, originally described as Sternarchus schotti by Steindachner (1868b). Since then, seven additional species of Sternarchella have been described that are currently recognized as valid (Lundberg et al., 2013; Ivanyisky, Albert, 2014) (Tab. 1). Sternarchella curvioperculata Godoy, 1968 described from the upper rio Paraná basin was excluded from Sternarchella by Lundberg et al. (2013), based on the presence of numerous small scales above the lateral line (13-14 versus 5-9 in Sternarchella). Based on visual inspection of the illustration and photograph of the specimen in the description (not available for physical examination), we determine that Sternarchella curvioperculata most closely resembles a member of the clade Apteronotus sensu stricto (Albert, 2001).
Here we describe two new species of Sternarchella (Tab. 1), resolve the confusion between species boundaries in the $S$. schotti species complex, provide redescriptions for all valid species of Sternarchella and provide range extensions for two species of Sternarchella. We also provide an updated maximum-parsimony phylogeny based on 76 morphological characters for Sternarchella and Magosternarchus (Lundberg et al., 1996) and synonymize the genus Magosternarchus with Sternarchella. Furthermore, we provide a key of identification for all valid species of Sternarchella.

\section{Materials and Methods}

Taxon sampling. Ingroup sampling included all valid species of Sternarchellini (sensu Ivanyisky, Albert, 2014) (S1 - Available only as online supplementary file accessed with the online version of the article at http://www.scielo.br/ni). Museum acronyms are as presented in Ivanyisky, Albert (2014). The following outgroup Apteronotinae genera were used to polarize character states: Apteronotus, Compsaraia, Magosternarchus, Parapteronotus, Pariosternarchus, Porotergus and Sternarchogiton. Characters were coded from morphologically mature specimens as evidenced by the degree of ossification of the sphenoid region and total length relative to largest reported specimen.

Tab. 1. Summary of taxonomic data on valid species of Sternarchella.

\begin{tabular}{|c|c|c|c|c|c|c|}
\hline Species & Author & Year & Type Locality & State & Basin & Clade \\
\hline $\begin{array}{l}\text { Sternarchella } \\
\text { calhamazon }\end{array}$ & Lundberg et al. & 2013 & $\begin{array}{l}\text { rio Madeira, } 35 \mathrm{~km} \text { above confluence } \\
\text { with rio Amazonas }\end{array}$ & Amazonas, Brazil & Amazon & S. calhamazon (D) \\
\hline Sternarchella duccis & Lundberg et al. & 1997 & $\begin{array}{l}\text { Roraima, Brazil, rio Branco, } 3-11 \mathrm{~km} \\
\text { upriver from confluence with rio Negro }\end{array}$ & Amazonas, Brazil & Amazon & S. duccis $(\mathrm{C})$ \\
\hline Sternarchella orinoco & Mago-Leccia & 1994 & Delta of río Orinoco at Isla Iguana & Amacuro, Venezuela & Orinoco & S. sima (A) \\
\hline Sternarchella orthos & Mago-Leccia & 1994 & río Apure near mouth of río Boqueronis & Apure, Venezuela & Amazon, Orinoco & S. schotti (B) \\
\hline $\begin{array}{l}\text { Sternarchella patriciae, } \\
\text { new species }\end{array}$ & herein & 2016 & $\begin{array}{l}\text { río Madre de Dios } 2 \mathrm{~km} \text { upstream bridge } \\
\text { at Puerto Maldonado }\end{array}$ & Madre de Dios, Peru & Amazon & S. calhamazon (D) \\
\hline Sternarchella raptor & Lundberg et al. & 1997 & $\begin{array}{l}\text { Amazonas, Brazil, rio Solimões, } 17 \mathrm{~km} \\
\text { downriver from confluence of río Purus }\end{array}$ & Amazonas, Brazil & Amazon & S. duccis (C) \\
\hline $\begin{array}{l}\text { Sternarchella rex, new } \\
\text { species }\end{array}$ & herein & 2016 & $\begin{array}{l}\text { Mamirauá Lake System, Paraná Maiana } \\
\text { station A }\end{array}$ & Amazonas, Brazil & Amazon & S. calhamazon (D) \\
\hline Sternarchella schotti & Steindachner & 1868 & Mouth of rio Negro at Manaus & Amazonas, Brazil & Amazon, Orinoco & S. schotti (B) \\
\hline Sternarchella sima & Starks & 1913 & Pará (Belém) & Pará, Brazil & Amazon & S. $\operatorname{sim} a(\mathrm{~A})$ \\
\hline
\end{tabular}

External Morphology. Morphometric measurements were collected using digital calipers following Ivanyisky, Albert (2014). Fourteen measurements were taken: LEA (length from the tip of the snout to end of anal fin), AFL (length from base of the anal fin to the end of the anal fin), HD1 (a measure of head depth through the nape), HD2 (A measure of head depth through the eye), HL (Distance from distal edge of opercle to the tip of the snout), PR (head length from the tip of the snout, to the front of the eye), PO (head length from the back of the eye, to the distal edge of the opercle), IO (distance between eyes from dorsal aspect), ED (diameter of the eye), HW (head width), MW (mouth width), PA (distance between the anus and the anal-fin origin), CPD (caudal peduncle depth), CPL (caudal peduncle length). Due to high levels of damage and regeneration in the tail region, body proportions taken as proportions of total length are unreliable; instead we used LEA.

Geometric morphometric methods were used in addition to traditional morphometrics to capture shape features of the head, as part of an analysis of intraspecific variation in $S$. orthos between three populations: the western Amazon, the eastern Amazon and the Orinoco river basin. Photographs of 30 adult specimens were taken using a Nikon Coolpix digital camera with specimen orientations standardized. Photos were converted to .tps files using tpsUtil (Rohlf, 2008), and 15 homologous landmarks were positioned on each photograph using 
tpsDig2 (Rohlf, 2006) (Fig. 1). The resulting tpsDig2 files were then imported into Morpho J (Klingenberg, 2011) and a Procrustes superimposition performed to remove the effects of size and scaling on specimens. A principal components analysis (PCA) was then performed to capture the primary axes of variance in the shape data.

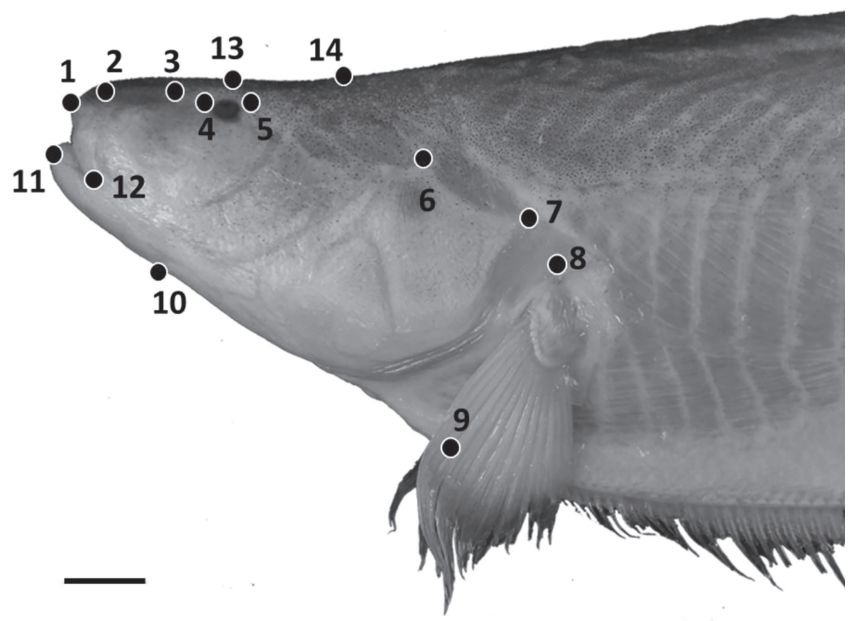

Fig. 1. Positions of 14 homologous landmarks of the head used in geometric morphometric analyses. Photo of Sternarchella orthos (FMNH 115236). Scale bar $=15 \mathrm{~mm}$.

Osteology. Osteological information was collected after clearing and staining (C\&S) specimens following Taylor, Van Dyke (1985), modified using xylene washes following Ivanyisky, Albert (2014). Specimens were dissected following Weitzman (1974) with modifications by Albert (2001). Osteological Illustrations were made using an Olympus SZX-12 stereomicroscope fitted with a camera lucida. Osteological information was also collected from digital radiographs using a Kevex MicroFocus X-ray Source and Varian PaxScan image receptor at the Academy of Natural Sciences in Philadelphia, and a Kodak DXS Pro digital X-ray system at the University of Central Florida. Meristic measurements consisted of anal-fin ray counts, anterior unbranched anal-fin ray counts, and pre-caudal vertebrae counts.

Phylogenetic methods. We coded 76 morphological characters to construct a phylogeny using Maximum Parsimony (MP) (S2 - Available only as online supplementary file accessed with the online version of the article at http://www.scielo.br/ni). Characters were selected on the basis of phylogenetic informativeness (Pimentel, Riggins, 1987). All osteological characters were collected from mature specimens as evidenced by the degree of ossification in the sphenoid, palatoquadrate and coracoid regions (Albert, 2001). Osteological nomenclature follows Albert (2001). A MP analysis was run in TNT (Goloboff et al., 2008) using a data matrix of 76 characters and 16 taxa. Seven apteronotid species were used as outgroup taxa to infer polarity, selected on the basis of results from earlier studies (see Ivanyisky, Albert, 2014). Polymorphic states were coded with "\&". Parapteronotus hasemani was designated as the outgroup taxa for the parsimony analysis in TNT. A heuristic search was implemented using an implicit enumeration algorithm in TNT using 15,000 replicates. All multi-state characters were treated as unordered. Bremer Supports (Bremer, 1994) were run with 1000 replicates in TNT. Nodes with Bremer Supports lower than one were collapsed.

Electric Signals. Head-to-tail electric organ discharge (htEOD) waveforms were recorded from live specimens of Sternarchella rex by WGRC, within 12 hours of capture. Specimens were recorded in a loose nylon mesh envelope suspended in the center of an $88 \times 37 \mathrm{~cm}$ insulated cooler filled to a depth of $34 \mathrm{~cm}$. Single ht-EODS were taken from tank-end $\mathrm{Ag} / \mathrm{Ag}-\mathrm{Cl}$ or $\mathrm{NiCr}$ electrodes, using a custombuilt AC-coupled amplifier (DC - $30 \mathrm{kHz}$ ) and digitized at $48 \mathrm{kHz}$ to digital audio tape (and later redigitized to 96 $\mathrm{kSs}$ at 24-bit resolution using an Edirol UA5 analog-digital converter). Water temperature was standardized to 27.0 $+/-0.1{ }^{\circ} \mathrm{C}$, and conductivity to $55+/-1 \mu \mathrm{Scm}^{-1}$. The EOD frequency of gymnotiforms is temperature dependent. Therefore, prior to placement in the mesh envelope, each fish was transferred from a holding tank to the cooler and allowed to move freely for a few minutes until the EOD fundamental frequency stabilized. EOD recordings are reported here with specimen numbers following the format year-month-day-sequential number.

\section{Results}

Character descriptions. A recent phylogenetic study of the Sternarchellini was conducted by using 70 morphological and osteological characters (Ivanyisky, Albert, 2014). This current study revises the previous character scheme (S3 Available only as online supplementary file accessed with the online version of the article at http://www.scielo.br/ni). Here we exclude character 61 (the shape of a process on the fourth epibranchial) because it was not phylogenetically informative, and add an additional nine characters, described here following the previous numbering scheme. Membership of clades A (S. sima clade), B (S. schotti clade), C ( $S$. duccis clade), D (S. calhamazon clade), are summarized in Tab. 1, and described below under 'Clade Diagnoses'.

Skull. Character 67. Margin of parietal and supraoccipital. 0 : Margin of parietal and supraoccipital smooth lacking thorny ridges. 1: Ridge or crown of thorny projections present at the border between the parietals and the supraoccipital that is continuous throughout the dorsal margin of the epioccipital and the pterotic (Fig. 2a).

This character is found in some of the larger predatory Sternarchella species (S. orthos and S. patriciae), whose diet was determined by gut-content analyses. However, this 
character is not directly linked to size as it is conspicuously absent in large-bodied congeners; i.e. S. orinoco, S. rex, S. schotti, and $S$. sima. It is likely that the thorny projections are sites for increased muscle attachment for jaw muscles possibly correlated to a more active, predatory lifestyle.

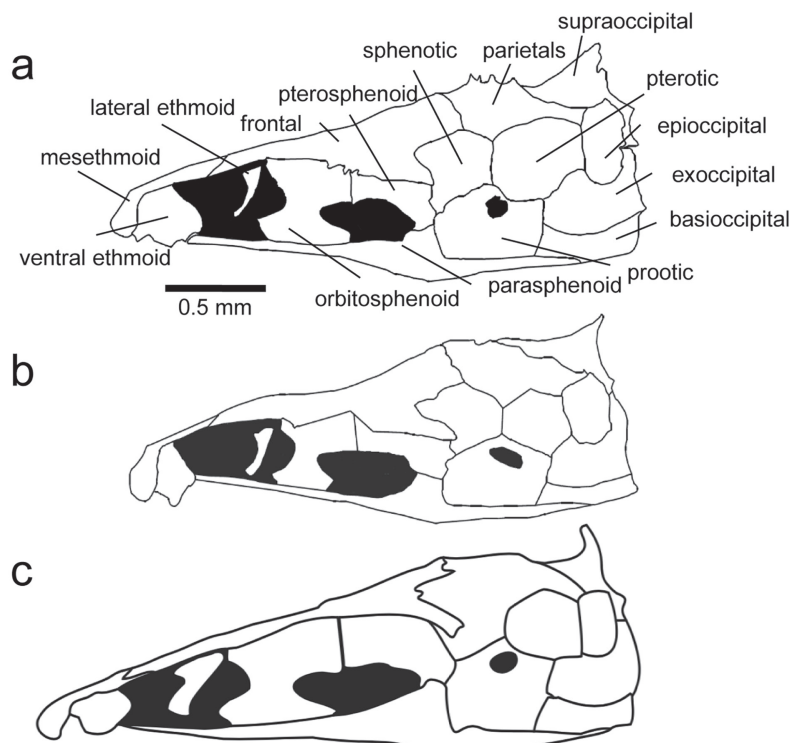

Fig. 2. Illustrations of neurocrania in lateral view of species in the Sternarchella calhamazon clade. a. Sternarchella patriciae (MUSM 45234) showing the 'crown of thorns' at the border of the parietal and supraoccipital bones. b. Sternarchella calhamazon (USNM 373113), showing the smaller and triangular ventral ethmoid. c. Sternarchella rex paratype (MCP 49423).

Character 73. Posterior margin of dentary. 0: Curves gradually to descending limb. 1: Posterior margin of dentary deeply forked (Ivanyisky, Albert, 2014).

This character is shared by two species in the $S$. calhamazon clade (S. calhamazon and S. patriciae), and may be associated with the superior mouth and stout appearance of the dentary bone in these species.

Branchial basket. Character 56. Second basibranchial. 0: Hour-glass shaped with most narrow portion at mid length. 1: Fan- or rod-shaped, extending to long narrow end. 2: Triangular with a short posterior portion (length of posterior rod-shaped portion less than half the width of the anteriorly positioned fan-shaped portion; Fig. 3).

The hour-glass shape of the second basibranchial is present in all species of the $S$. calhamazon clade. It was found that this condition is the ontogenetic precursor to the fan-shaped condition. Juvenile $S$. orthos were found to possess this condition later on ossifying the spaces on the side resulting ultimately in a fan- or rod shaped appearance seen in adult $S$. orthos and $S$. schotti.

Character 74. First hypohyal. 0: First hypohyal bell- or cylinder-shaped. 1: First hypohyal triangular, its posterior margin longer than any other margin of bone (Fig. 3).
Caudal peduncle. Character 68 . Rows of bones in caudal peduncle. 0: Single row of bones visible in caudal peduncle. 1: Two parallel rows of bones visible in caudal peduncle. This character was originally described by Lundberg et al. (2013) in their description of $S$. calhamazon. This character is also observed in S. patriciae and S. rex.
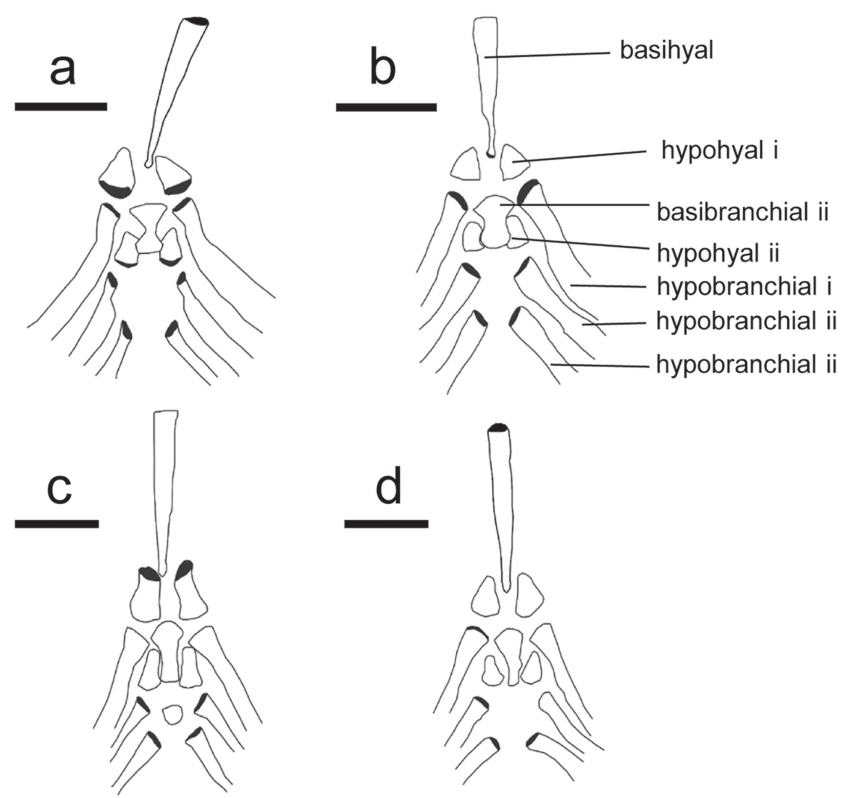

Fig. 3. Dorsal view of the brachial basket in four species of Sternarchella. a. Sternarchella patriciae (MUSM 45234). b. Sternarchella orinoco (USNM 228727). c. Sternarchella schotti (UF 116570). d. Sternarchella orthos (USNM 228871). Scale bar $=0.5 \mathrm{~mm}$. Note differences in the shape of the second basibranchial, ranging from hourglass shaped, to fan-shaped, and differences in the shape in the hypohyal, ranging from bell-or cylinder shaped, to a wide-based triangular shape. Grey shaded areas indicate three-dimensional features.

Character 70. 0: Caudal peduncle depth shallow less than 30\% HL. 1: Caudal peduncle deep greater than $30 \%$ HL (Lundberg et al., 2013). This character was also described in Lundberg et al. (2013) and was originally thought to be associated with the two rows of bones in the caudal peduncle (Character 68). However, in S. patriciae these two characters are not always linked.

Gymnotiformes often exhibit partially regenerated tails which confound measurements of characters in the caudal region. However, with large sample sizes and non-regenerated specimens, this character can be used to differentiate between species (Albert, Crampton, 2009).

Character 72. Caudal peduncle dark spot. 0: Dark spot absent on caudal peduncle. 1: Dark spot present on caudal peduncle (Tagliacollo et al., 2016).

Character 75. Caudal peduncle margin. 0: Continuous membrane of tissue connecting anal-fin base and caudal peduncle. 1: No apparent connective tissue between analfin base and caudal peduncle. 
Proximal anal-fin pterygiophores. Character 76. Proximal anal-fin pterygiophores. 0: Longer than corresponding hemal spines 1: Shorter than hemal spines (Lundberg et al., 2013). This character was used by Lundberg et al. (2013) to discriminate $S$. calhamazon from all other species of Sternarchella; however, it is now understood that $S$. patriciae also possesses this character.

Displaced hemal spines. Character 69. 0: One to two displaced hemal spines with a straight lower half of descending blades. 1: Four to five displaced hemal spines laterally curved on lower half of descending blades (Fig. 4). This character was described by Lundberg et al. (2013) as an additional character to distinguish $S$. schotti from all other Sternarchella species. This character is associated with the elongate swim bladder found only in S. schotti. a

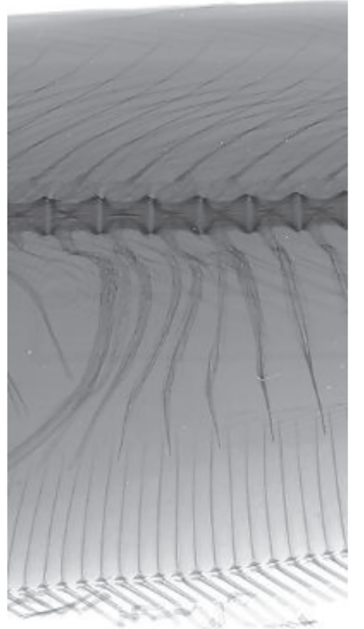

b

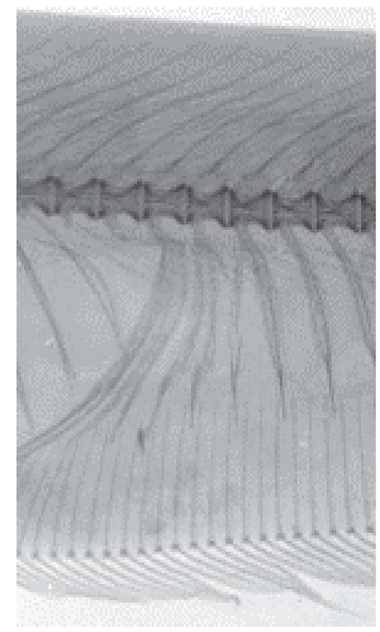

Fig. 4. Radiographs of holotypes of two Sternarchella species showing condition of displaced hemal spines at posterior margin of body cavity. a. Sternarchella terminalis holotype (CAS 54912). b. Sternarchus schotti holotype (NMW 65335).

Key to the adults of the genus Sternarchella with notes on distribution

1a. Mouth terminal or superior; interorbital distance small, less than $20 \% \mathrm{HL}$

1b. Mouth sub-terminal; four rows of teeth present on premaxilla ... 3

2a. PA less than $50 \%$ head length; $0-1$ rows of intermuscular bones visible in caudal peduncle ... 4

$2 \mathrm{~b}$. PA greater than $50 \%$ head length; 2 rows of intermuscular bones visible in caudal peduncle.

3a. Tail length exceeds head length; interorbital distance small, less than $20 \% \mathrm{HL}$ S. orinoco (OR)

$3 b$. Tail length less than head length; body depth equal or greater than $\mathrm{HL}$ S. $\operatorname{sima}(\mathbf{E A})$ 4a. Swim bladder long, extending beyond posterior margin of body cavity; eye diameter large, $7.6 \% \mathrm{HL}$ or more....

S. schotti (EA, WA, OR*)

4b. Swim bladder short extending less than half the length of the body cavity; eye diameter small less than $7.0 \%$ head length

\section{7}

5a. More than 180 anal-fin rays; head wide, distance between lateral margins $46 \% \mathrm{HL}$ or more S. $\operatorname{rex}(\mathrm{WA})$

5b. Less than 180 anal-fin rays; head narrow distance between lateral margins less than $45 \% \mathrm{HL}$

6a. Caudal peduncle depth greater than $27 \%$ head length; crown of thorny projections at border of parietal and supraoccipital, and epioccipital ridges (Fig. 2a)

S. patriciae (UM)

6b. Caudal peduncle depth less than $27 \%$ head length; body cavity short, 14 or less precaudal vertebrae

S. calhamazon (EA, WA)

7a. Maxilla sickle shaped with no anterior process present....

S. orthos (EA, WA, OR, UM)

7b. Large teeth, robust anterior process of maxilla present 8 8a. Mouth superior S. duccis (EA, WA) 8b. Mouth terminal. S. raptor (EA, WA)

Eastern Amazon (EA), Western Amazon (WA), Orinoco (OR), Upper Madeira (UM).

$\left({ }^{*}\right)$ One juvenile specimen of $S$. schotti was collected in the rio Meta in Colombia.

Synonymy of Magosternarchus. We recovered a paraphyletic Sternarchella, with Magosternarchus nested inside it (Fig. 5). This topology was also recovered in Ivanyisky, Albert (2014) and Tagliacollo et al. (2016). A recent paper by Ferraris et al. (2017) recently used the name "Sternarchella" in reference to the Magosternarchus species citing the findings from Ivanyisky, Albert (2014) as grounds for synonomy. However, in the aforementioned manuscript, no formal synonomy was ever provided. Consequently, we herein recognize the genus Magosternarchus as a junior synonym of Sternarchella and we refer to M. duccis and M. raptor as $S$. duccis and S. raptor, respectively.

Synapomorphies of Sternarchella. Members of the genus Sternarchella can be diagnosed from all other members of the family Apteronotidae by the following characters: -Premaxilla large, lateral margin of premaxilla longer than lateral margin of maxilla (Albert, 2001; fig. 6). -Ventral margin of maxillary blade curved evenly towards its distal tip (but see S. raptor) (Albert, 2001: figs. 7-8). -Ventral ethmoid large and robust with a large fan-shaped lateral process (Albert, 2001). -Dorsomedial portion of orbitosphenoids in contact (visible through anterior fontanel in dorsal view; Ivanyisky, Albert, 2014). -Opercle broad, width over half depth (Ivanyisky, Albert, 2014). 


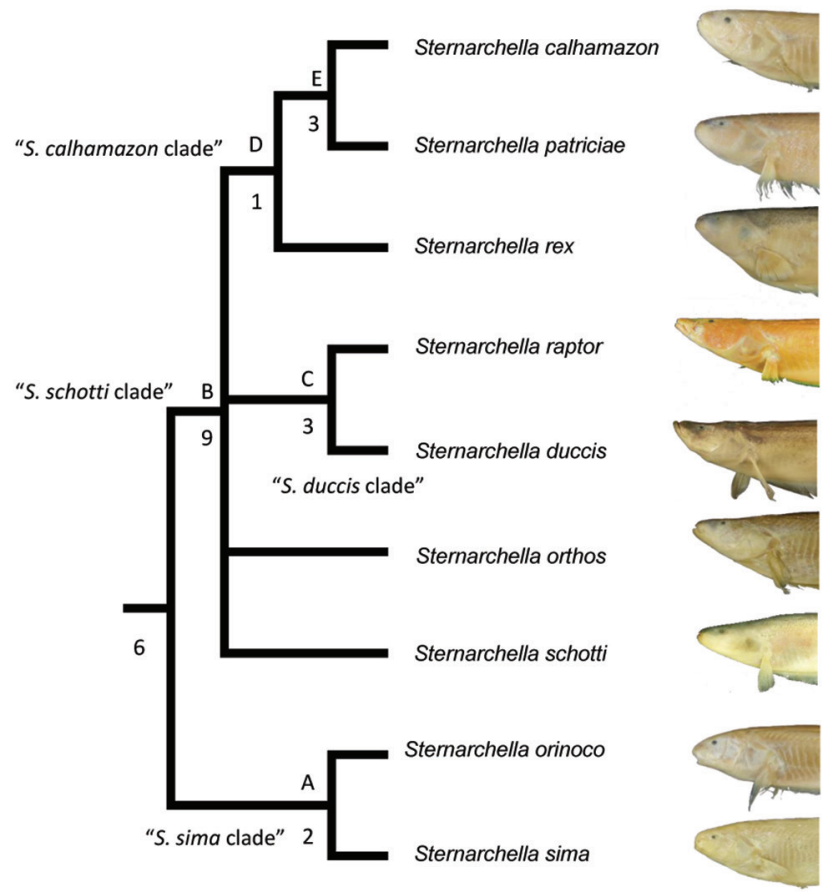

Fig. 5. Phylogenetic tree of Sternarchella resulting from a maximum parsimony analysis of the 76 morphological characters in Appendix 1 (S1 - Available only as online supplementary file accessed with the online version of the article at http://www. scielo.br/ni). Bremer supports shown to the left of nodes. Clades labeled by letters and names as in text and Tab. 1 .

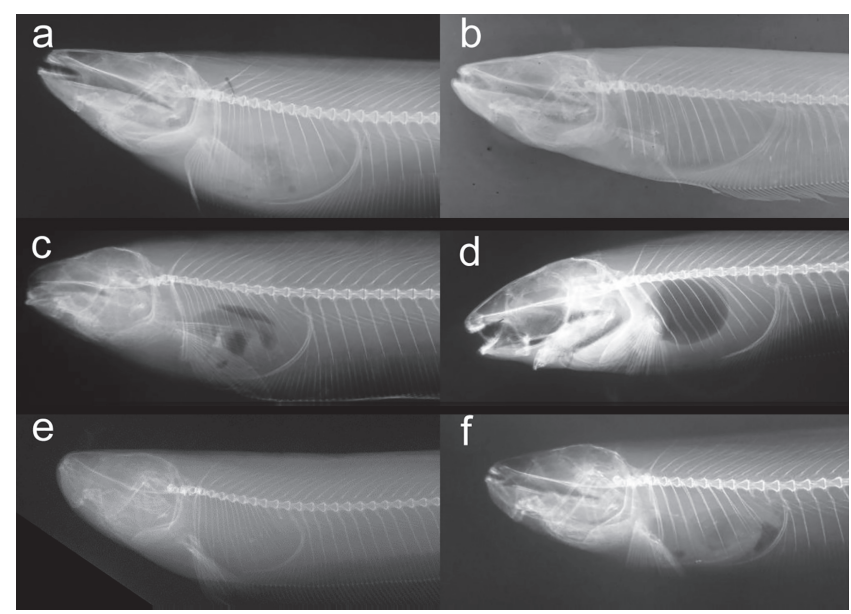

Fig. 6. Radiographs of six of the nine valid Sternarchella species. a. S. orthos (USNM 228871). b. S. schotti (NMW 65335, holotype). c. S. sima (AMNH 3864, holotype). d. $S$. orinoco (USNM 228727). e. S. calhamazon (INPA 37898, holotype). f. S. patriciae (MUSM 45239, holotype).

Clade A (S. sima clade): Comprised of Sternarchella species with a ventral mouth ( $S$. sima and $S$. orinoco), and characterized by six synapomorphies. Pectoral fin large, $80 \% \mathrm{HL}$ or greater. Oral aperture sub-terminal, upper jaw extends anteriorly to lower jaw. Four rows of teeth present on premaxilla. Three to four rows of teeth present on dentary. Endopterygoid large, contacting frontal.
Clade B (S. schotti clade): Comprised of Sternarchella species with a terminal or superior mouth, and characterized by 15 synapomorphies. PA\% moderate, $46-49 \%$ HL. Post orbital distance small, 60-67\% HL. Interorbital distance small, 14-22\% HL. Oral aperture terminal, upper and lower jaws equal in length. Premaxilla triangular in ventral view. Two to three rows of teeth present on premaxilla. Dorsoanterior portion of mesethmoid straight. Anterior tip of mesethmoid scyphate on dorsal surface. Lateral ethmoid very robust, may contact ventral portion on frontals, hourglass shaped with narrowest point at mid-length. Dorsal margin of supraoccipital crest extends beyond dorsal margin of parietals. Endopterygoid process small, not contacting frontal. Endopterygoid process extends vertically at or near a $90^{\circ}$ angle with dorsal surface of endopterygoid. Base of gill rakers contacting gill arch. Second basibranchial fanshaped, extending to long narrow end. First hypohyal bellor cylinder shaped.

Clade C ( $S$. duccis clade): Comprised of $S$. duccis and $S$. raptor, and characterized by five synapomorphies. Rictus extends ventral to nasal capsule, gape more than three times eye diameter. Two rows of teeth present on premaxilla. Anterior process of maxilla large and broad, extending more than one half length of descending blade in mature specimens. Posterior fontanel longer than anterior fontanel. Twelve or less teeth present on pharyngobranchial.

Clade D (S. calhamazon clade): Comprised of S. calhamazon, $S$. patriciae, and S. rex. This clade is characterized by five synapomorphies. PA\% large, 59-61\% HL. Mouth wide, distance between lateral ricti $20-27 \%$ HL. Body base color with a pale or whitish hue. Two rows of bones in caudal peduncle visible externally. Continuous membrane of tissue connecting anal-fin base and caudal peduncle.

Clade E: Comprised of S. calhamazon and S. patriciae. This clade is characterized by six synapomorphies. Oral aperture superior, lower jaw extends anteriorly to upper jaw. Two, one, or no rows of teeth present on premaxilla. Lateral ethmoid large hour-glass shaped, most narrow portion at mid-length. Endopterygoid large, contacting frontal. Posterior margin of dentary deeply forked. Anal-fin proximal small, shorter than hemal spine.

Diversity of craniofacial shapes in Sternarchella. Among Sternarchella species, craniofacial shapes range from a rounded snout with a sub-terminal mouth in the S. sima clade, to a straight snout with a terminal mouth in the $S$. schotti clade (excluding the $S$. calhamazon clade), to a straight snout with a superior mouth in the $S$. calhamazon clade (Fig. 6). This diversity in craniofacial shapes is generally consistent with the trophic ecology of these fishes as estimated from gut content analysis (discussed in further detail in species descriptions and redescriptions). Mouth position is correlated with different feeding strategies in 
many fishes, including silver arowanas (Osteoglossum bicirrhosum), which use a superior mouth to launch aerial attacks on surface dwelling prey (Lowry et al., 2005), and sturgeons (Acipenser oxyrinchus) that use sub-terminal mouths to foraging on small-bodied epibenthic and infaunal aquatic animals (Johnson et al., 1997). This pattern of mouth position as an indicator of trophic ecology has also been extensively documented in cichlids (Montaña, Winemiller, 2013; Rüber, Adams, 2001).

Gut content analyses of indicates a rough association between craniofacial phenotypes and diet among Sternarchella species. Species in the $S$. sima clade with a sub-terminal mouth feed primarily on benthic animals such as aquatic crustaceans and arthropod larvae and fish remains have never been recovered in the guts of sub-terminal mouthed species (Evans, pers. obs.). The dietary range of species with a terminal or superior mouth species is much wider. Remains of small-bodied doradid catfishes have been found in guts of small-bodied specimens (100 mm LEA) of S. calhamazon, while other specimens of similar size from the same collection locality had only planktonic cladoceran larvae. All Sternarchella species with a terminal or superior mouth have robust oral and pharyngeal jaws and robust gill-rakers, allowing them to feed at several trophic levels. Sternarchella duccis and S. raptor also have robust oral and pharyngeal dentition and well developed gill rakers, and have been reported to specialize on consuming the tails of other electric fishes (Lundberg et al., 1996). In examining gut-contents of both species for this study we observed scales neatly stacked in the stomachs of both juveniles and adults in the absence of other fish tissue, suggesting facultative lepidophagous habits (Sazima, 1983). These preliminary findings suggest that these species exhibit a highly specialized piscivorous lifestyle, feeding primarily on external body parts of other fishes.

\section{Taxonomic accounts}

\section{Sternarchella patriciae, new species}

Fig. 7, Tab. 2

urn:1sid:zoobank.org:act:69ECF190-DC1E-445A-839A08ADD219D1B4

Sternarchella calhamazon. -Ivanyisky, Albert, 2014:569: fig. 3G [Peru, Madre de Dios, Río Los Amigos].

Sternarchella sp. -Crampton, Cella-Ribeiro, 2013:274 [Peru, Madre de Dios].

Holotype. MUSM 45239, 175 mm LEA, male, Peru, Madre de Dios state, Río Madre de Dios $2 \mathrm{~km}$ upstream bridge at Puerto Maldonado, 12³2'44'S 69¹0'34'W, $178 \mathrm{~m}$ elevation, 21 May 2011, J. S. Albert.

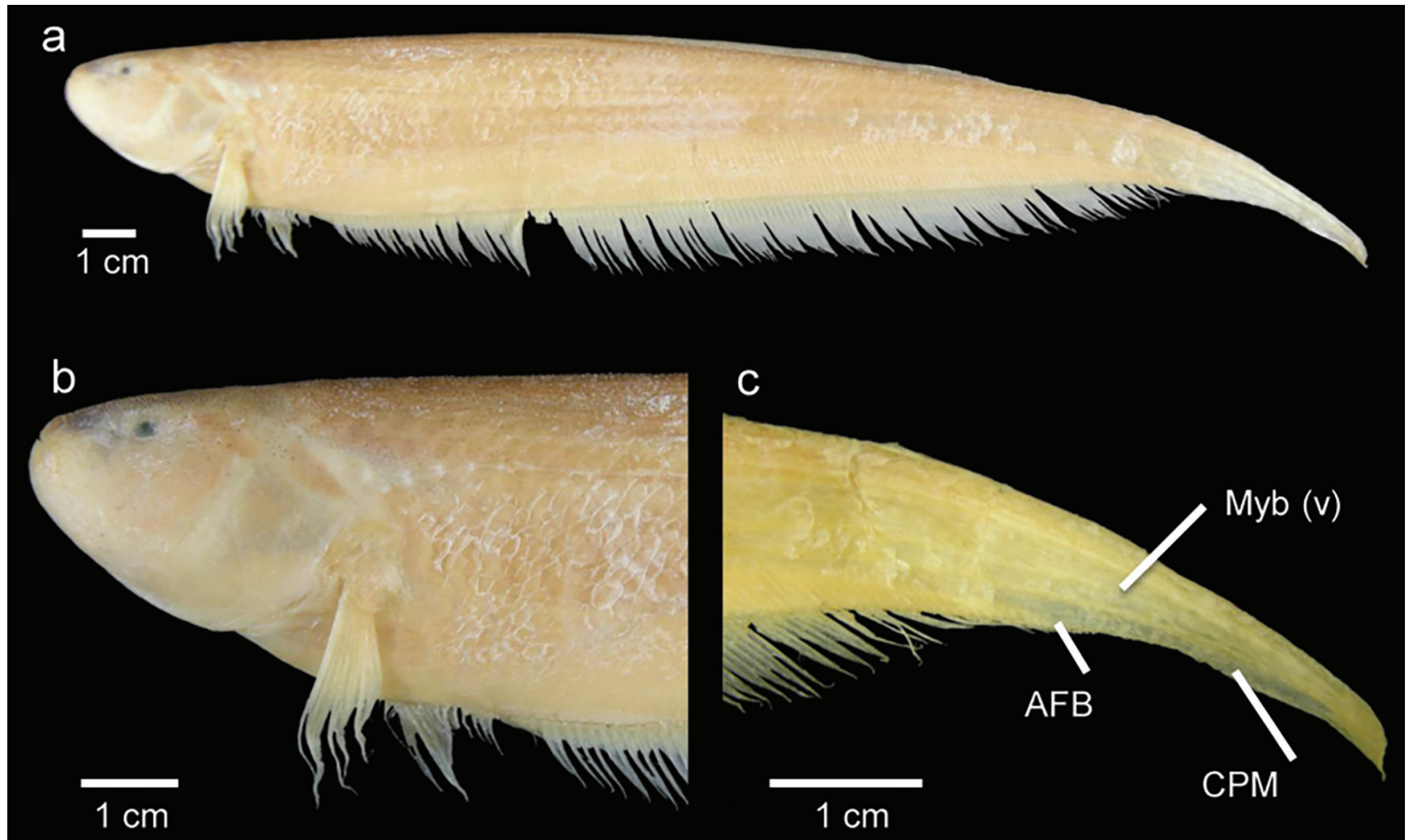

Fig. 7. Sternarchella patriciae holotype (MUSM 45239). a. Lateral view of the body, b. Head and anterior portion of body, c. Caudal region showing two rows of intermuscular bones (Myb), the anal-fin base (AFB) and the continuous caudal peduncle membrane (CPM). 
Tab. 2. Morphometrics and meristic measurements for Sternarchella patriciae. Ranges include holotype.

\begin{tabular}{lccccc}
\hline Characters & Holotype & Minimum & Maximum & Mean & $\mathrm{n}$ \\
\hline LEA (mm) & 175 & 156.0 & 208.0 & 176.7 & 19 \\
AFL & 147 & 133.0 & 180.0 & 150.6 & 19 \\
HD1 & 12.1 & 12.0 & 19.7 & 14.6 & 19 \\
HD2 & 19.3 & 16.9 & 26.0 & 19.4 & 19 \\
HL & 24.8 & 23.4 & 31.3 & 26.5 & 19 \\
PR & 6.8 & 7.0 & 9.2 & 7.7 & 19 \\
PO & 16.4 & 15.0 & 20.5 & 16.9 & 19 \\
ED & 1.7 & 1.6 & 3.1 & 2.0 & 19 \\
IO & 3.9 & 3.9 & 5.9 & 4.7 & 19 \\
HW & 10.5 & 9.0 & 14.4 & 10.8 & 19 \\
MW & 4.2 & 4.7 & 6.7 & 5.5 & 19 \\
PA & 15.5 & 13.1 & 22.4 & 16.6 & 19 \\
CPD & 7.2 & 4.9 & 8.0 & 6.6 & 19 \\
CPL & 21 & 10.0 & 29.0 & 19.2 & 19 \\
AFR & 173 & 164 & 191 & 174 & 19 \\
Unbranched AFR & 19 & 15 & 29 & 19 & 19 \\
Pre-caudal vertebrae & 14 & 14 & 15 & - & 5 \\
& & Percent HL & & & \\
PR\% & 4.0 & 2.9 & 4.5 & 3.8 & 19 \\
PO\% & 28.41 & 24.1 & 32.2 & 29.0 & 19 \\
ED\% & 64.6 & 59.9 & 67.6 & 63.9 & 19 \\
IO\% & 0.1 & 6.4 & 10.7 & 7.7 & 19 \\
HW\% & 18.4 & 15.1 & 20.3 & 17.6 & 19 \\
MW\% & 36.9 & 36.2 & 47.8 & 40.7 & 19 \\
PA\% & 20.3 & 18.1 & 24.7 & 20.9 & 19 \\
CPD\% & 0.6 & 54.0 & 71.6 & 62.4 & 19 \\
CPL\% & 26.2 & 18.6 & 30.3 & 25.1 & 19 \\
CPD/CPL & 66.4 & 41.5 & 92.6 & 72.0 & 19 \\
HL/LEA & 66.4 & 25.7 & 49.0 & 35.4 & 19 \\
LEA/CPD & 15.4 & 13.5 & 15.6 & 15.0 & 19 \\
PR/PO & & & & & \\
\hline & 19.7 & 45.4 & 19 \\
\hline
\end{tabular}

Paratypes. ANSP 197615, 7, 167-200 mm LEA. Peru, Madre de Dios state, Río Madre de Dios $2 \mathrm{~km}$ upstream bridge at Puerto Maldonado, 12³2'44”S 69¹0'34”W, 178 m elevation, 21 May 2011, J. S. Albert.

Non-types. ANSP 197616, 2, 168-208 mm LEA. Peru, Madre de Dios state, Río Madre de Dios, Los Amigos Biological station $12^{\circ} 18^{\prime} 10.35^{\prime \prime} \mathrm{S} 70^{\circ} 23^{\prime} 0.89^{\prime \prime} \mathrm{W}$. MUSM 45233, 9, 171-200 mm LEA, Peru, Madre de Dios, Río Los Amigos, Los Amigos Biological station, $12^{\circ} 18^{\prime} 10.35^{\prime \prime} \mathrm{S}$ $70^{\circ} 23^{\prime} 0.89^{\prime \prime} \mathrm{W}$. MUSM 45234, 1, $175 \mathrm{~mm}$ LEA, Peru, Madre de Dios, Río Los Amigos, Los Amigos Biological station, $12^{\circ} 18^{\prime} 10.35^{\prime \prime} \mathrm{S} 70^{\circ} 23^{\prime} 0.89^{\prime \prime} \mathrm{W}$.

Diagnosis. Sternarchella patriciae can be distinguished from all congeners by the presence of two rows of bones visible externally in caudal peduncle ( $v$ s. one row in $S$. duccis, S. orinoco, $S$. orthos, S. raptor, S. sima, and S. schotti) (shared with $S$. calhamazon and $S$. rex), the presence of a continuous membrane of tissue connecting the anal-fin base and caudal peduncle (vs. no membrane in $S$. duccis, $S$. orinoco, $S$. orthos, $S$. raptor, $S$. sima, and $S$. schotti) (shared with $S$. calhamazon and $S$. rex), the presence of a long body-cavity (14-15 pre-caudal vertebrae $v s$. 12-14 in S. calhamazon and 16 in S. duccis, S. orinoco, S. rex, S. sima, and S. schotti) (shared with S. orthos and S. raptor), the possession of a ridge or crown of thorny projections at border of parietal and supraoccipital and epioccipital ridges (Fig. 2a; vs. absent $S$. calhamazon, $S$. duccis, $S$. orinoco, S. raptor, $S$. rex, $S$. schotti, and $S$. sima) and the presence of a ridge on the posterior dorsal surface of the basihyal (vs. ridge absent in $S$. calhamazon) (shared with $S$. duccis, S. orinoco, S. orthos, $S$. sima, S. schotti, S. rex, and S. raptor).

Description. A medium-sized apteronotid species, reaching $208 \mathrm{~mm}$ LEA. Pectoral fin size small, less than $80 \%$ HL. PA\% large, 54-72\% HL. Head width narrow, distance between lateral margins 36-48\% HL. Preorbital (snout) length moderate, $24-32 \%$ HL. Postorbital distance large, $60-68 \%$ HL. Eye diameter large, 6-11\% HL. Interorbital distance small, 15-20\% HL. Mouth wide, distance between ricti $18-25 \%$ HL. Body depth less than HL. Scales absent on posterolateral portion of body. Scales large in size with 5-8 present above lateral line at mid-body. Scales dorsal to lateral line rhomboid at mid-body. Rictus extends to a vertical with mental symphysis, gape very small, less than twice eye diameter. Oral aperture superior, lower jaw extends anteriorly to upper jaw. Body cavity long; 14-15 pre-caudal vertebrae present. Proximal surface of first displaced hemal spine narrower then descending blade. One to two displaced hemal spines. Swim bladder not extending posterior to body cavity. Anal-fin pterygiophore length equal to or shorter than hemal spines. Anal-fin proximal small, shorter than hemal spine. Two rows of bones in caudal peduncle visible externally. Caudal peduncle shallow, 19-30\% HL. Dark spot on caudal peduncle absent. Continuous membrane of tissue connecting anal-fin base and caudal peduncle. Caudal peduncle length short, less than HL. Lateral margin of premaxilla longer than lateral margin of maxilla. Premaxilla triangular in ventral view. Two rows of teeth present on premaxilla. Anterior hook of maxilla absent, anterior process broad and triangular with a continuous ventral margin with descending blade. Anterior process of maxilla extending as a shelf of bone less than one-third length of descending blade. Ventral margin of maxillary blade curves evenly towards its distal tip. Descending blade maxilla thin, evenly curved. Two rows of teeth present on dentary. Dentary longer than deep, oral margin of dentary longer than length of angular articular. Dorsal margin of dentary slightly concave in lateral view. Posterior margin of dentary deeply forked. Endopterygoid large, contacting frontal. Endopterygoid process extends vertically at or near a $90^{\circ}$ angle with dorsal surface of endopterygoid. Endopterygoid process slender with a narrow tip. Hyomandibula short, its width half its length. Dorsal margin of opercle concave. Opercle broad, width over half depth. Anterior limb of cleithrum length greater than cleithrum ascending limb length. Post-temporal fused with 
supracleithrum in mature specimens. Ventral ethmoid large and robust with a large fan-shaped lateral process. Dorso-anterior portion of mesethmoid straight. Anterior tip of mesethmoid scyphate on dorsal surface. Anterior fontanel longer than posterior fontanel. Lateral ethmoid large, hour-glass shaped, most narrow portion at mid-length. Orbitosphenoid broad, well ossified in median nasal septum with ventral margin longer than dorsal margin. Dorso-medial portion of orbitosphenoids in contact (visible through anterior fontanel in dorsal view). Absence of ventral process of pterosphenoid, anterior ventral margin of pterosphenoid similar to posterior ventral margin of orbitosphenoids. Lateral process of parasphenoid small, lateral margins of parasphenoid not extending to a horizontal with trigeminal foramen. Parasphenoid ventral margin straight or slightly curved. Distance between parietal ridges narrow, just lateral to supraoccipital, parietal ridges very large and pronounced. Crown of thorny projections present at border of parietals and supraoccipital, continuing to epioccipital. Dorsal margin of supraoccipital crest extends beyond dorsal margin of parietals. Supraoccipital crest extends to a dorsal distal tip. Internal carotid foramen reduced. Ventral surface of basioccipital smooth. Anterior extension of infraorbital canal shorter than width of canal pore, anterior canal pore of infraorbital near first infraorbital. Supraorbital canal fused to frontal. Mandibular canal size small. Mandibular canal ossicles form long slender tubes. Supratemporal laterosensory canal curved at a sharp angle on surface of parietal, extending posterior onto epaxial surface of body, terminal canal pore oriented posteriorly, epidermis overlying supratemporal canal depigmented. Base of gill rakers contacting gill arch. Gill rakers long with ossified distal tips. Dorsal surface of basihyal convex forming a robust ridge posteriorly. Second basibranchial hour-glass shaped with most narrow portion at mid-length. Third basibranchial unossified. Fourteen or more teeth present on pharyngobranchial. Eight or more teeth present on sixth hypobranchial. Medial surface of fourth hypobranchial with a process or bridge extending to meet contralateral process on midline. Urohyal blade unossified. First hypohyal bell-or cylinder shaped.

Coloration in alcohol. Yellowish white color, with a darker brown mid-dorsum along the length of the body, with light striations overlying and demarcating the ribs at the body cavity.

Sexual dimorphism. No sexual dimorphism found in 3 male and 7 female specimens.

Distribution and habitat. (Fig. 8). Specimens of Sternarchella patriciae were collected in the Madre de Dios in Peru by trawling the river bottom (Fig. 9). Individuals inhabit deep river channels $(10-20 \mathrm{~m})$ during the day and move to shallower water at night to feed near the river margin and over flooded beaches. Gut-content analysis indicates that these fishes feed primarily on larger-bodied (non-planktonic) aquatic insect larvae (e.g. Odonata and Ephemeroptera) and some juvenile fishes.

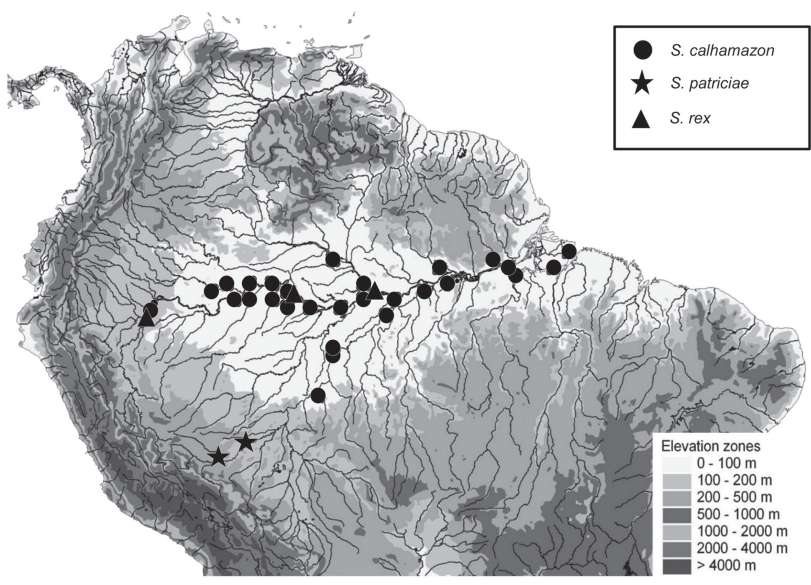

Fig. 8. Map of collection localities of species in the $S$. calhamazon species group. Sternarchella rex (triangles), $S$. patriciae (stars), and S. calhamazon (circles). Note: 1, the $S$. calhamazon species group is restricted to the Amazon basin; 2, the allopatric distribution of the sister species S. calhamazon and S. patriciae; and 3, S. calhamazon is represented at more sites than other members of the $S$. calhamazon species group. Base map of drainages provided by Conservation Science Program, World Wildlife Fund US; inset depicts elevations in gray shades.

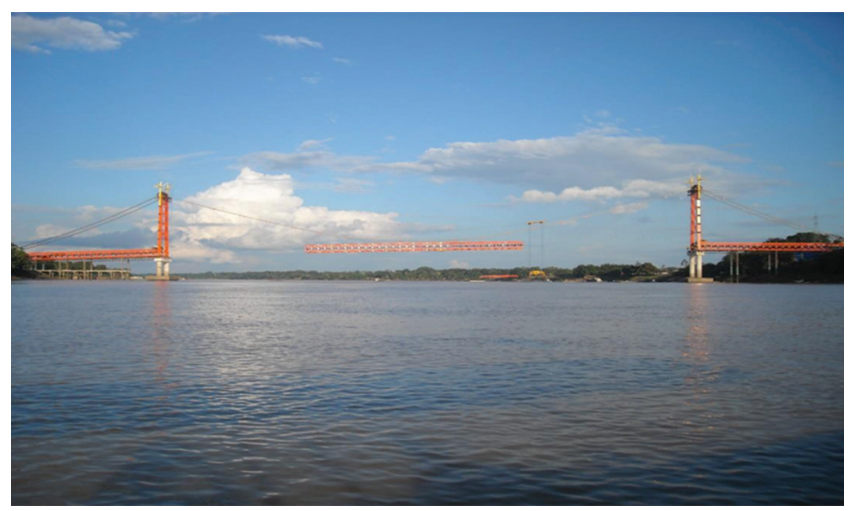

Fig. 9. Type locality of Sternarchella patriciae on the Río Madre de Dios, in front of Puerto Maldonado (Tambopata Department) near the confluence of the Tambopata River. Specimens were collected at about $10 \mathrm{~m}$ depth using a 12 foot shrimp trawl.

Etymology. Patronym in honor of Patricia Evans, a prominent civil-rights activist and community leader in Philadelphia, Pennsylvania.

Remarks. Sternarchella patriciae is a member of the $S$. calhamazon clade with which it shares six synapomorphies. Sternarchella patriciae also shares the highly predatory lifestyle of other Sternarchella species, and exhibits a peramorphic version of the $S$. calhamazon body plan. These relatively peramorphic characters are: more robust ossification of the skull among specimens of comparable size, more and larger muscle attachment sites on the skull (e.g. crown of thorns at border of parietal and supraoccipital 
and along ridge of epioccipital; Fig. 2a), a longer caudal peduncle (Fig. 10), more pre-caudal vertebrae (12-14 vs. 14-15), more teeth present on pharyngobranchial (14 or more vs. 12 or less), and an overall larger total body size $(80 \%$ larger). These phenotypes all allow feeding on larger prey items like small fishes and large aquatic invertebrates.

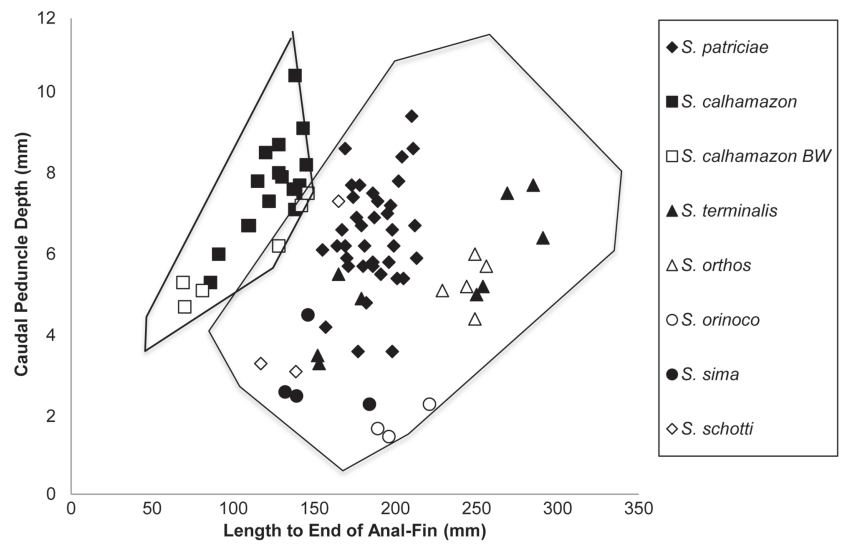

Fig. 10. Biplot of length to end of anal-fin (LEA) vs. caudal peduncle depth (CPD) for eight species of Sternarchella showing the separation between $S$. calhamazon from white water, S. calhamazon from black water (BW), and seven other Sternarchella species in CPD.
Sternarchella patriciae is allopatrically separated from S. calhamazon, and has to date only been found in the Madre de Dios basin in the upper Madeira basin in Peru. Genetic data are not yet available for $S$. patriciae. Genetic analyses of other fish taxa distributed in the upper Madeira and Lowland Amazon basins report varying levels of genetic differentiation, including difference described as within and between species (Albert, 2012; Albert, Reis, 2011; Farias et al., 2010; Ochoa et al., 2015; Torrente-Vilara et al., 2011).

\section{Sternarchella rex, new species}

Figs. 11-12a, Tab. 3

urn:1sid:zoobank.org:act:67F5A55F-A093-4512-861E0B53A27CECCB

Sternarchella n. sp. A. -Ivanyisky, Albert, 2014:569, fig. 3E [Brazil, rio Amazonas near Tefé]. -Crampton, Albert, 2006: 386: [Brazil, rio Amazonas near Tefé]. -Crampton, 2007:316, fig. 11.9 3E [Brazil, rio Amazonas near Tefé]. -Crampton, 2011:165-189 [Brazil, rio Amazonas near Tefé].

Holotype. MCP 49422, 405 mm LEA, Brazil, Tefé, Mamirauá Lake System, Paraná Maiana station A, 0306'44”S 6447’32”W, 28 Jan 1999, W. G. R. Crampton.

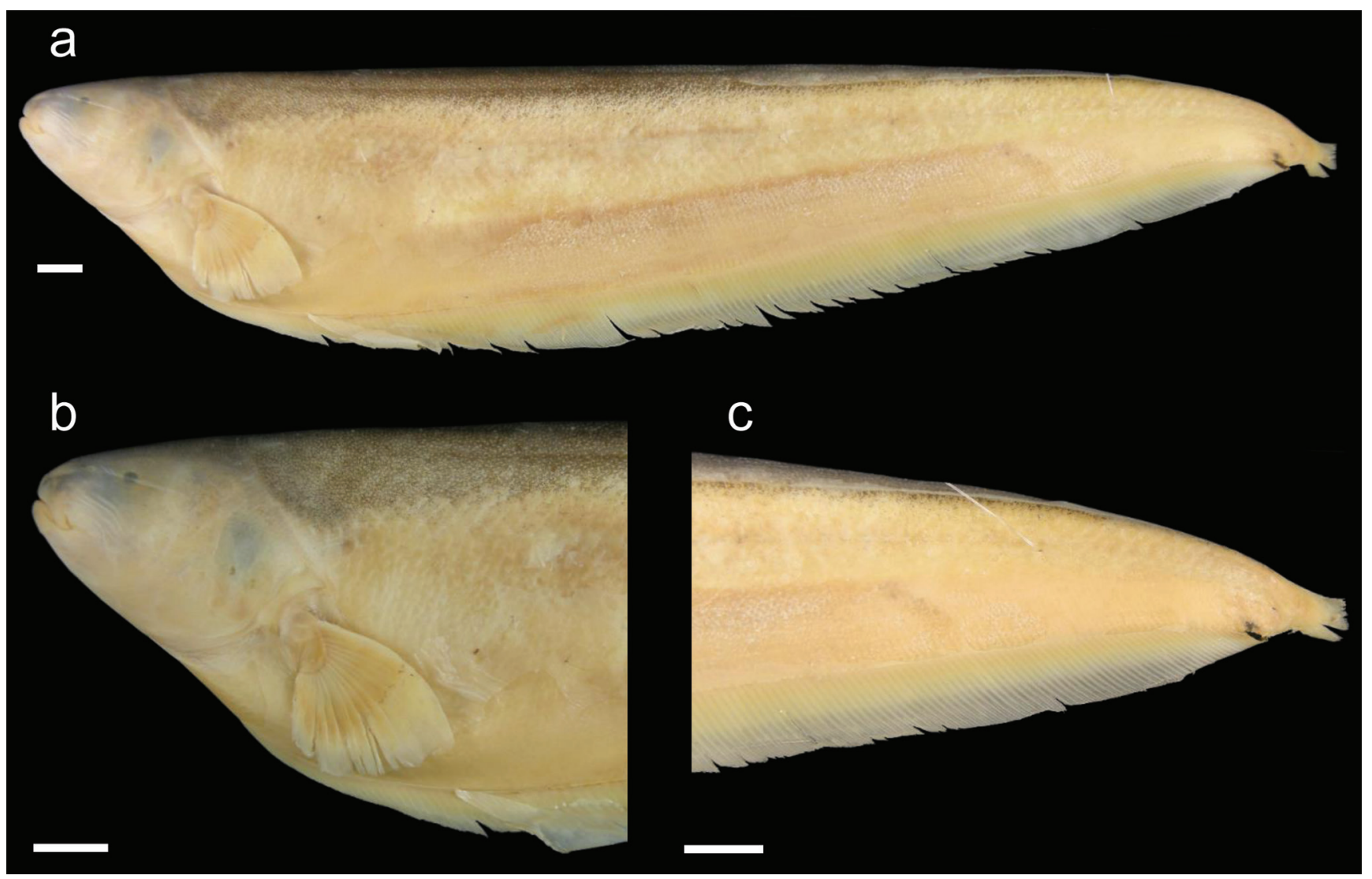

Fig. 11. Sternarchella rex (ANSP 200294). a. Lateral view of the body, b. Lateral view of the head, c. Lateral view of the caudal region. Scale bars $=1.5 \mathrm{~cm}$. 
Tab. 3. Morphometrics and meristic measurements for Sternarchella rex. Ranges include holotype.

\begin{tabular}{|c|c|c|c|c|c|}
\hline Characters & Holotype & Minimum & Maximum & Mean & $\mathrm{n}$ \\
\hline LEA (mm) & 405 & 295.0 & 405.0 & 343.2 & 5 \\
\hline AFL & 357 & 259.0 & 357.0 & 302.2 & 5 \\
\hline HD1 & 28 & 18.5 & 28.0 & 24.2 & 5 \\
\hline HD2 & 46.5 & 31.3 & 46.5 & 37.8 & 5 \\
\hline HL & 53.4 & 40.0 & 53.4 & 45.2 & 5 \\
\hline PR & 18.5 & 12.3 & 18.5 & 14.7 & 5 \\
\hline $\mathrm{PO}$ & 35.5 & 26.1 & 35.5 & 30.4 & 5 \\
\hline ED & 3.5 & 2.3 & 3.5 & 2.6 & 5 \\
\hline IO & 13 & 7.2 & 13.0 & 10.1 & 5 \\
\hline HW & 29 & 18.4 & 29.0 & 24.5 & 5 \\
\hline MW & 14.5 & 9.1 & 14.5 & 12.1 & 5 \\
\hline $\mathrm{PA}$ & 31.9 & 17.4 & 31.9 & 26.6 & 5 \\
\hline CPD & - & 8.1 & 10.3 & 9.0 & 4 \\
\hline CPL & - & - & - & - & - \\
\hline AFR & 214 & 180 & 214 & 205 & 5 \\
\hline Unbranched AFR & 20 & 17 & 24 & 21 & 5 \\
\hline Pre-caudal vertebrae & 16 & 15 & 16 & - & 12 \\
\hline \multicolumn{6}{|l|}{ Percent HL } \\
\hline $\mathrm{PR} \%$ & 34.6 & 30.1 & 34.6 & 0.3 & 5 \\
\hline $\mathrm{PO} \%$ & 66.5 & 64.2 & 72.5 & 0.7 & 5 \\
\hline $\mathrm{ED} \%$ & 6.5 & 5.2 & 6.5 & 0.1 & 5 \\
\hline $\mathrm{IO} \%$ & 24.3 & 18.0 & 27.0 & 0.2 & 5 \\
\hline HW\% & 54.3 & 46.0 & 63.5 & 0.5 & 5 \\
\hline MW\% & 27.1 & 22.7 & 32.0 & 0.3 & 5 \\
\hline $\mathrm{PA} \%$ & 59.7 & 43.5 & 65.9 & 0.6 & 5 \\
\hline $\mathrm{CPD} \%$ & - & 18.9 & 25.2 & 0.2 & 4 \\
\hline CPL\% & - & - & - & - & - \\
\hline $\mathrm{CPD} / \mathrm{CPL}$ & - & - & - & - & - \\
\hline HL/LEA & 13.2 & 12.4 & 13.6 & 0.1 & 5 \\
\hline LEA/CPD & - & 2.0 & 3.2 & 2.5 & 4 \\
\hline $\mathrm{PR} / \mathrm{PO}$ & 52.1 & 45.0 & 52.1 & 48.7 & 5 \\
\hline
\end{tabular}

Paratypes. INPA 18149, 1, 279 mm LEA. Brazil, Tefé, Mamirauá Lake System, Paraná Maiana station A, 0306'44”S 6447’32”W, 28 Jan 1999, W. G. R. Crampton. INPA 18150, 1, 373 mm LEA, Brazil, Tefé, Mamirauá Lake System, Paraná Maiana station C, $03^{\circ} 04^{\prime} 10^{\prime \prime S} 64^{\circ} 47^{\prime} 52^{\prime \prime} \mathrm{W}$, 5 Feb 1999, W. G. R. Crampton. MCP 49423, 2 (1 C/S), 365 mm LEA, Brazil, Tefé, Mamirauá Lake System, Paraná Maiana station A, 0306'44”S 6447’32”W, 28 Jan 1999. ZUEC 12337, 1, $305 \mathrm{~mm}$ LEA, Brazil, Tefé, rio Japurá at

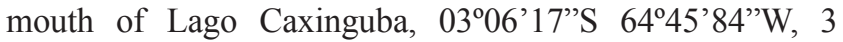
Feb 1999, W. G. R. Crampton. ZUEC 12338, 1, 313 mm LEA, Brazil, Tefé, rio Japurá, West bank at Boca do Lago Mamirauá, 0307’13”S 6447’30”W, 8 Dec 1999, W. G. R. Crampton.

Non-types. ANSP 200294, 1, 357 mm LEA, Peru, Iquitos, Loreto, Río Amazonas, 1 Jan 2015, M. J. Bernt. MUSM 54500, 6, 321-382 mm LEA, Peru, Iquitos, Loreto, Isla Milagro beach, East bank río Amazonas, upstream of
Iquitos, $7.64 \mathrm{~km}$ and $21.86^{\circ}$ from Plaza de Armas (Iquitos town center), $03^{\circ} 43^{\prime} 28^{\prime \prime} \mathrm{S} 73^{\circ} 12^{\prime} 31^{\prime \prime} \mathrm{W}, 17$ Dec 2015. UF 238215, 1, 271 LEA, Peru, Iquitos, Loreto, Isla Milagro beach, East bank río Amazonas, upstream of Iquitos, 7.64 $\mathrm{km}$ and $21.86^{\circ}$ from Plaza de Armas (Iquitos town center), 034'28”'S 073¹2’31”W, 19 Dec 2015.

Diagnosis. Sternarchella rex can be diagnosed from all congeners by the following combination of characters: a wide head, HW 46-64\% HL (vs. 36-45\% HL in all other Sternarchella), a large interorbital distance, IO 18-27\% HL (vs.11-22\% HL in S. calhamazon S. duccis, S. orinoco, $S$. orthos, S. patriciae, S. raptor, and S. schotti) (shared with $S$. sima), a deep body, depth greater than or equal to HL (vs. body depth less than HL in S. calhamazon, S. duccis, S. orinoco, S. orthos, S. patriciae, S. raptor, and S. schotti) (shared with $S$. sima), an ossified third basibranchial bone (vs. unossified in S. calhamazon, S. duccis, S. orinoco, $S$. orthos, S. patriciae, S. raptor, and S. sima) (shared with $S$. schotti) and anal-fin pterygiophores that are longer than hemal spines (vs. short anal-fin pterygiophores in S. duccis, $S$. orinoco, S. orthos, S. patriciae, S. raptor) (shared with S. calhamazon, S. patriciae, and S. schotti).

Description. Largest known species of Sternarchella reaching an LEA of $405 \mathrm{~mm}$. Pectoral fin size small, less than $80 \%$ HL. PA $\%$ large, $44-66 \%$ HL. Head wide, distance between lateral margins 46-64\% HL. Preorbital (snout) length moderate, $30-35 \%$ HL. Postorbital distance large, 64-73\% HL. Eye diameter small, 5-7\% HL. Interorbital distance large, 18-27\% HL. Mouth wide, distance between ricti $22-32 \%$ HL. Body depth equal or greater than HL. Body pale white with pinkish and metallic green sheen in living specimens. Scales absent on posterolateral portion of body. Scales large in size with 5-8 present above lateral line at mid-body. Scales dorsal to lateral line rhomboid at midbody. Rictus extends to a vertical with mental symphysis, gape very small, less than twice eye diameter. Oral aperture terminal, upper and lower jaws equal in length. Body cavity long, 15-16 pre-caudal vertebrae present. Proximal surface of first displaced hemal spine narrower then descending blade. One to two displaced hemal spines. Swim bladder not extending posterior to body cavity. Anal-fin pterygiophore length longer than hemal spines. Proximal anal-fin pterygiophores long, equal or longer than hemal spines. Two rows of bones in caudal peduncle visible externally. Dark spot on caudal peduncle absent. Continuous membrane of tissue connecting anal-fin base and caudal peduncle. Premaxilla large, lateral margin of premaxilla longer than lateral margin of maxilla. Premaxilla triangular in ventral view. Three rows of teeth present on premaxilla. Anterior hook of maxilla absent, anterior process broad and triangular with a continuous ventral margin with descending blade. Anterior process of maxilla extending as a shelf of bone less than one-third length of descending blade. Ventral margin of maxillary blade curves evenly towards its distal 
tip. Descending blade maxilla thin, evenly curved. Two rows of teeth present on dentary. Dentary longer than deep, oral margin of dentary longer than length of angular articular. Dorsal margin of dentary slightly concave in lateral view. Posterior margin of dentary curves gradually to descending limb. Endopterygoid process small, not contacting frontal. Endopterygoid process extends vertically at or near a $90^{\circ}$ angle with dorsal surface of endopterygoid. Endopterygoid process oblique (greater than $90^{\circ}$ ). Hyomandibula short, its width half its length. Dorsal margin of opercle concave. Opercle broad, width over half depth. Anterior limb of cleithrum length greater than cleithrum ascending limb length. Post-temporal fused with supracleithrum in mature specimens. Ventral ethmoid large and robust with a large fan-shaped lateral process. Dorso-anterior portion of mesethmoid straight. Anterior tip of mesethmoid scyphate on dorsal surface. Anterior fontanel longer than posterior fontanel. Lateral ethmoid robust, may contact ventral portion on frontals. Orbitosphenoid broad, well ossified in median nasal septum with ventral margin longer than dorsal margin. Dorso-medial portion of orbitosphenoids in contact (visible through anterior fontanel in dorsal view). Absence of ventral process of pterosphenoid, anterior ventral margin of pterosphenoid similar to posterior ventral margin of orbitosphenoids. Lateral process of parasphenoid small, lateral margins of parasphenoid not extending to a horizontal with trigeminal foramen. Parasphenoid ventral margin straight or slightly curved. Distance between parietal ridges narrow, just lateral to supraoccipital, parietal ridges are very large and pronounced. Dorsal margin of supraoccipital crest extends beyond dorsal margin of parietals. Supraoccipital crest extends to a dorsal distal tip. Internal carotid foramen reduced, less than half the size of prootic foramen. Ventral surface of basioccipital smooth. Anterior extension of infraorbital canal short. Supraorbital canal fused to frontal. Mandibular canal size small. Mandibular canal ossicles form long slender tubes. Supratemporal laterosensory canal curved at a sharp angle on surface of parietal, extending posterior onto epaxial surface of body, terminal canal pore oriented posteriorly, epidermis overlying supratemporal canal depigmented. Base of gill rakers contacting gill arch. Gill rakers long with ossified distal tips. Dorsal surface of basihyal convex forming a robust ridge posteriorly. Second basibranchial hour-glass shaped with most narrow portion at mid-length. Third basibranchial ossified. Fourteen or more teeth present on pharyngobranchial. Eight or more teeth present on sixth hypobranchial. Medial surface of fourth hypobranchial with a process or bridge extending to meet contralateral process on midline. Urohyal blade unossified. First hypohyal bellor cylinder-shaped.

Coloration in alcohol. Yellowish white color, with a light brown mid-dorsum along the length of the body. Live specimens are pale white in color with a green sheen along the dorsum (Fig. 12a).

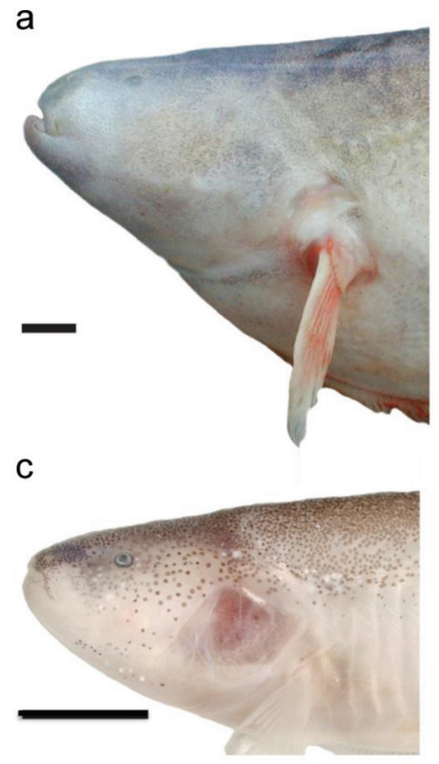

b

Fig. 12. Photographs heads of live specimens of four syntopic species of Sternarchella from the vicinity of Tefé, Amazonas, Brazil. a. Sternarchella rex holotype (MCP 49422). b. Sternarchella schotti (MCP 49429. c. Sternarchella calhamazon (MCP 49420. d. Sternarchella orthos (MCP 49436). Scale bar $=10 \mathrm{~mm}$. The flanks of this fish were considerably paler moments before this photograph was taken.

Sexual dimorphism. Not known, insufficient number of male and female specimens to determine.

Distribution and habitat. (Fig. 8).The type series, from the vicinity of Tefé, Amazonas, Brazil, was collected only during the early rising water period of December-February (Fig. 13). Four of the six specimens in the type series were collected from a "paraná" channel located in whitewater 'várzea' inundation forest of the Mamirauá Reserve (paranás are narrow side channel of whitewater rivers that traverse adjacent floodplain). Sternarchella rex specimens were caught at depths of 2-4 m with seine nets deployed from the middle of the paraná channel to the edge. The substrate comprised mud and organic debris.

Seven additional non-type specimens of $S$. rex were collected from silt and fine sand beaches on the margins of the río Amazonas near the city of Iquitos, Loreto, Peru - all at depths of 3-10 m. These specimens were captured during the late part of the rising water period in December (Fig. 13).

The stomach contents of four specimens of S. rex in the type series from the Tefé region (one non-recorded specimen, and three which were recorded very soon after capture), and seven from the Iquitos region were examined. All stomachs contained unidentified fish scales, skin and fine bones. Aquatic arthropods were conspicuously absent. We noted that all specimens of $S$. rex had damage to the caudal fin and fin-base, as is common in wild caught gymnotiforms from riverine habitats. This was probably caused by predators. 


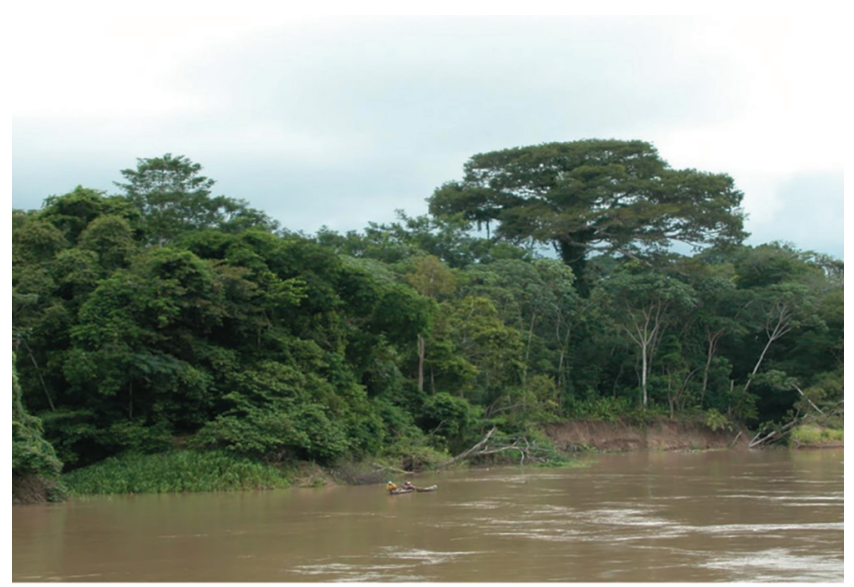

Fig. 13. Amazon River margin habitat near type locality of Sternarchella rex in Tefé, Brazil. Specimens were collected using $50 \times 6 \mathrm{~m}$ or $50 \times 8 \mathrm{~m}$ beach seine nets operated in the mid-channel and edges of whitewater floodplain channels of the río Solimões-Japurá confluence, and on beaches of the río Japurá near its confluence with the río Solimões (Amazon).

Electric Organ Discharges. The ht-EODs of five of the type series were recorded (Fig. 14). The ht-EOD comprises a wave-type waveform with two peaks in each cycle. A dominant biphasic component is followed by a secondary peak of positive polarity (Fig. 14, left). The waveform dips to near the zero voltage baseline between the two peaks (in some cases exhibiting a constant (flat) low voltage, only slightly positive to the baseline) and crosses the baseline twice during the main biphasic component. The fundamental frequency varied in recorded specimens from 945-1096 Hz, mean $1023 \mathrm{~Hz}$, standard deviation $54 \mathrm{~Hz}$ ). The power spectral density computed from a Fast Fourier Transform (Fig. 14, right) exhibits a harmonic distribution of energy, as is typical for wave-type gymnotiform ht-EODs (Crampton, Albert, 2006). In all but one specimen the peak (dominant) frequency of the power spectral density corresponds not to the fundamental frequency, but to the first harmonic. In one specimen (1999-02-03-05), the peak frequency corresponded to the second harmonic. Although none of these specimens were in full reproductive condition, two were sexed as male (fundamental frequency 945-1096 $\mathrm{Hz}$ ) and one as female (fundamental frequency 1027 $\mathrm{Hz}$ ), with no sexual dimorphism of EOD fundamental frequency (as is known for some apteronotids, Crampton, Albert, 2006).

Etymology. This species name rex from the Latin word for king, in reference its large body size and robust appearance. An adjective.

Remarks. This species is the largest known species of Sternarchella reaching a maximum adult body size of 412 mm LEA.

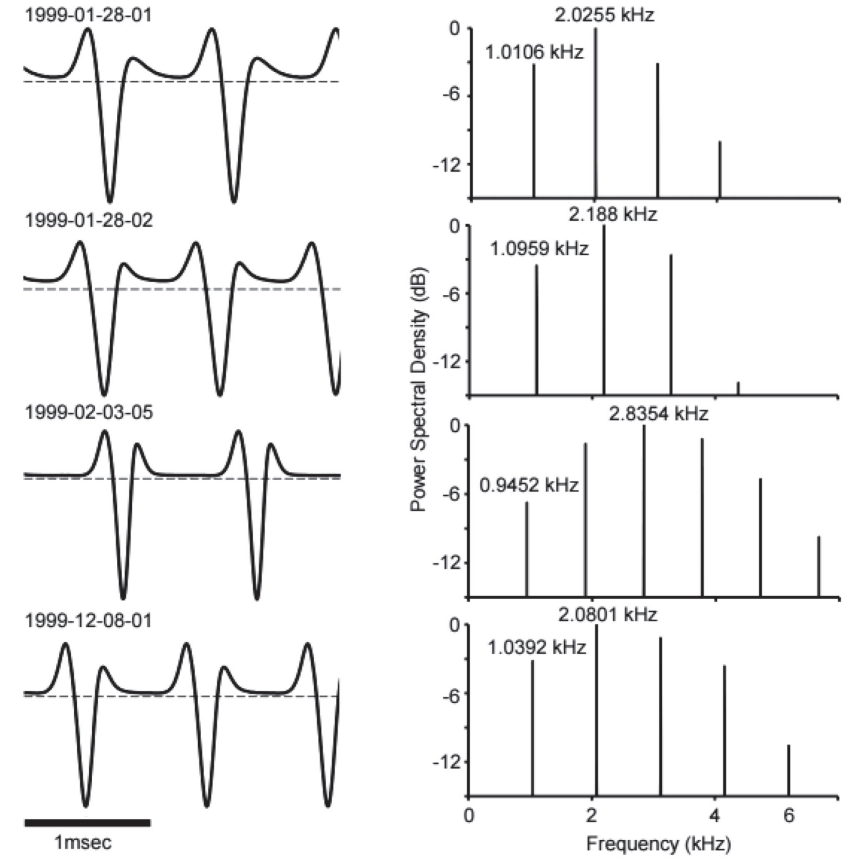

Fig. 14. Head-to-tail electric organ discharge (ht-EOD) waveforms (left) of Sternarchella rex, with corresponding power spectral density (PSD) computed by 65536-point Fast Fourier Transform from a 3s digital recording (right). Waveforms are plotted head-positive upwards with voltage on ordinate (not plotted to equal scale) and absolute time on abscissa. Horizontal dashed line denotes zero V. PSDs are scaled with the peak power frequency (PPF) scaled to 0 decibels (dB). Specimen 1999-01-28-01, immature = holotype, MCP 49422; specimen 1999-01-28-02, male (Nikolsky gonad stage 2) = paratype, INPA 18149; specimen 1999-02-03-05, male (Nikolsky gonad stage 2) = paratype, ZUEC 12338; specimen 1999-12-08-01, immature = paratype, ZUEC 12338. Ht-EOD waveform not shown for recording of 1999-02-05-02, female (Nikolsky gonad-stage 2) = paratype, INPA 18150 due to poor recording quality (nonetheless the fundamental frequency was measurable from this recording as $1027 \mathrm{~Hz}$, with PPF corresponding to the first harmonic.

\section{Sternarchella calhamazon Lundberg, Cox Fernandes \& Campos-Da-Paz, 2013}

Fig. 15, Tab. 4

Sternarchella calhamazon Lundberg et al., 2013:159, figs. 1, 2a, b [type locality: Pará, Brazil, rio Madeira, $35 \mathrm{~km}$ above confluence with rio Amazonas. Collected with $3 \mathrm{~m}$ bottom trawl in channel 14-16 m deep, $400 \mathrm{~m}$ off linear beach and bank, $\left.3^{\circ} 35^{\prime} 44.2^{\prime \prime} \mathrm{S} 58^{\circ} 57^{\prime} 45.8^{\prime \prime} \mathrm{W}\right]$.

Sternarchella n. sp. B. -Crampton, Albert, 2006:386 [Brazil, rio Amazonas near Tefé]. -Crampton, 2007:316: fig. 11.6 3E [Brazil, rio Amazonas near Tefé]. -Crampton, 2011:165-189 [Brazil, rio Amazonas near Tefé].

Sternarchella sp. -Crampton, Cella-Ribeiro, 2013:274-275, [Brazil, rio Madeira]. 


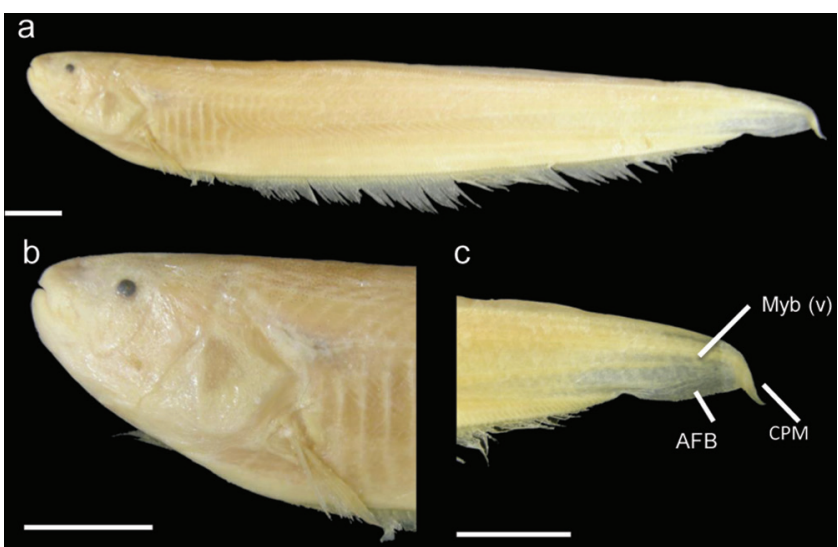

Fig. 15. Sternarchella calhamazon (USNM 373113). a. Lateral view of the body, b. Lateral view of the head, c. Lateral view of the caudal region showing two rows of intermuscular bones in the caudal peduncle and the continuous caudal peduncle membrane. Scale bars $=1 \mathrm{~cm}$.

Tab. 4. Morphometrics and meristic measurements for Sternarchella calhamazon.

\begin{tabular}{|c|c|c|c|c|}
\hline Characters & Minimum & Maximum & Mean & $\mathrm{n}$ \\
\hline LEA (mm) & 115.0 & 145.0 & 128.2 & 12 \\
\hline $\mathrm{AFL}$ & 94.0 & 118.3 & 102.6 & 12 \\
\hline HD1 & 10.4 & 15.0 & 11.9 & 12 \\
\hline HD2 & 14.2 & 21.7 & 16.2 & 12 \\
\hline HL & 19.0 & 26.3 & 21.7 & 12 \\
\hline PR & 4.9 & 7.8 & 5.9 & 12 \\
\hline $\mathrm{PO}$ & 11.7 & 16.9 & 14.1 & 12 \\
\hline ED & 1.4 & 1.8 & 1.6 & 12 \\
\hline IO & 3.0 & 4.2 & 1.6 & 12 \\
\hline HW & 7.2 & 11.5 & 8.5 & 11 \\
\hline MW & 3.5 & 5.1 & 4.2 & 11 \\
\hline PA & 10.8 & 19.2 & 13.0 & 11 \\
\hline $\mathrm{CPD}$ & 6.1 & 10.4 & 7.6 & 12 \\
\hline CPL & 11.0 & 16.4 & 12.1 & 12 \\
\hline AFR & 147 & 165 & 156 & 8 \\
\hline Unbranched AFR & 12 & 15 & 13 & 8 \\
\hline Pre-caudal vertebrae & 12 & 14 & - & 8 \\
\hline \multicolumn{5}{|c|}{ Percent HL } \\
\hline $\mathrm{PR} \%$ & 22.0 & 30.8 & 27.2 & 12 \\
\hline $\mathrm{PO} \%$ & 61.6 & 69.7 & 64.9 & 12 \\
\hline $\mathrm{ED} \%$ & 5.7 & 9.0 & 7.3 & 12 \\
\hline $\mathrm{IO} \%$ & 11.9 & 19.9 & 15.9 & 11 \\
\hline HW\% & 36.5 & 43.7 & 39.6 & 11 \\
\hline MW\% & 16.7 & 22.7 & 19.7 & 11 \\
\hline $\mathrm{PA} \%$ & 49.8 & 73.0 & 60.6 & 11 \\
\hline $\mathrm{CPD} \%$ & 27.3 & 42.1 & 35.1 & 12 \\
\hline CPL\% & 46.8 & 66.1 & 55.7 & 12 \\
\hline $\mathrm{CPD} / \mathrm{CPL}$ & 45.7 & 77.6 & 63.4 & 12 \\
\hline HL/LEA & 14.7 & 18.1 & 16.8 & 12 \\
\hline LEA/CPD & 4.7 & 7.5 & 5.9 & 12 \\
\hline $\mathrm{PR} / \mathrm{PO}$ & 33.6 & 49.7 & 42.0 & 12 \\
\hline
\end{tabular}

Diagnosis. Sternarchella calhamazon can be diagnosed from all congeners by the presence of a flat posterior dorsal surface of the basihyal ( $v s$. ridge in all other Sternarchella species), the presence of twelve or fewer teeth on pharyngobranchial (vs. 14 or more in all other Sternarchella species), the possession of a small body cavity usually with less than 14 pre-caudal vertebrae present (vs. 14 or more in all other Sternarchella species), the absence of a crown of thorny projections present at border of parietals and supraoccipital (vs. present in $S$. patriciae and $S$. orthos) (shared with $S$. duccis, $S$. orinoco, $S$. rex, S. raptor, S. schotti, and S. sima), and the possession of a deep caudal peduncle, 27-42\% HL (vs. 15-21\% HL in all other species of Sternarchella).

Description. Smallest known species of Sternarchella reaching an LEA of $169 \mathrm{~mm}$. Pectoral fin size small, less than $80 \%$ HL. PA \% large, 50-73\% HL. Head width narrow, distance between lateral margins 37-44\% HL. Preorbital (snout) length moderate, 22-31\% HL. Postorbital distance small, 62-70\% HL. Eye diameter small, 6-9\% HL. Interorbital distance small, 12-20\% HL. Mouth wide, distance between ricti $17-23 \%$ HL. Body depth less than HL. Body translucent in living specimens, yellow or pink hue in living specimens. Scales absent on posterolateral portion of body. Scales large in size with 5-8 present above lateral line at mid-body. Scales dorsal to lateral line rhomboid at mid-body. Rictus extends to a vertical with mental symphysis, gape small, less than twice eye diameter. Oral aperture superior, lower jaw extends anteriorly to upper jaw. Body cavity short, 14 or fewer pre-caudal vertebrae present. Proximal surface of first displaced hemal spine narrower then descending blade. One to two displaced hemal spines. Swim bladder not extending posterior to body cavity. Anal-fin pterygiophore length equal to or shorter than hemal spines. Proximal anal-fin pterygiophores long, equal or longer than hemal spines. Two rows of bones visible externally in caudal peduncle. Caudal peduncle deep, $27-42 \%$ HL. Dark spot on caudal peduncle absent. Continuous membrane of tissue connecting anal-fin base and caudal peduncle. Caudal peduncle length short, less than HL. Premaxilla large, lateral margin of premaxilla longer than lateral margin of maxilla. Premaxilla triangular in ventral view. Two rows of teeth present on premaxilla. Anterior hook of maxilla absent, anterior process broad and triangular with a continuous ventral margin with descending blade. Anterior process of maxilla extending as a shelf of bone less than one-third length of descending blade. Ventral margin of maxillary blade curves evenly towards its distal tip. Descending blade maxilla thin, evenly curved. Two rows of teeth present on dentary. Dentary longer than deep, oral margin of dentary longer than length of angular articular. Dorsal margin of dentary slightly concave in lateral view. Endopterygoid process extends vertically at or near a $90^{\circ}$ angle with dorsal surface of endopterygoid. Hyomandibula short, its width half its length. Dorsal margin of opercle concave. Opercle broad, width over half depth. Anterior limb of cleithrum length greater than ascending 
limb length. Post-temporal fused with supracleithrum in mature specimens. Ventral ethmoid large and robust with a large fan-shaped lateral process. Dorso-anterior portion of mesethmoid straight. Anterior tip of mesethmoid scyphate on dorsal surface. Anterior fontanel longer than posterior fontanel. Lateral ethmoid large hour-glass shaped, most narrow portion at mid-length. Orbitosphenoid broad, well ossified in median nasal septum with ventral margin longer than dorsal margin. Dorso-medial portion of orbitosphenoids in contact (visible through anterior fontanel in dorsal view). Absence of ventral process of pterosphenoid, anterior ventral margin of pterosphenoid similar to posterior ventral margin of orbitosphenoids. Lateral process of parasphenoid small, lateral margins of parasphenoid not extending to a horizontal with trigeminal foramen. Parasphenoid ventral margin straight or slightly curved. Distance between parietal ridges narrow, lateral to supraoccipital, parietal ridges are very large and pronounced. No thorny projections present at border of parietal and supraoccipital. Dorsal margin of supraoccipital crest exceed dorsal margin of parietals. Supraoccipital crest extends to a dorsal distal tip. Internal carotid foramen reduced. Ventral surface of basioccipital smooth. Anterior extension of infraorbital canal short. Supraorbital canal fused to frontal. Mandibular canal size small. Mandibular canal ossicles form long slender tubes. Supratemporal laterosensory canal curved at a sharp angle on surface of parietal, extending posterior onto epaxial surface of body, terminal canal pore oriented posteriorly, epidermis overlying supratemporal canal depigmented. Endopterygoid large, contacting frontal. Base of gill rakers contacting gill arch. Gill rakers long with ossified distal tips. Dorsal surface of basihyal flat; small ridge may be present posteriorly. Second basibranchial hour-glass shaped with most narrow portion at mid-length. Third basibranchial unossified. Twelve or less teeth present on pharyngobranchial. Eight or more teeth present on sixth hypobranchial. Medial surface of fourth hypobranchial with a process or bridge extending to meet contralateral process on midline. Urohyal blade unossified. First hypohyal bell- or cylinder shaped.

Coloration in alcohol. Yellowish white color, with a light brown mid-dorsum along the length of the body. In life, this species is pale white with a pink hue (Fig. 12c).

Sexual dimorphism. No sexual dimorphism found in 21 male and 15 female specimens.

Distribution and habitat. (Fig. 8). Distributed throughout the Amazon basin, where it inhabits deep river channels. Sternarchella calhamazon is one of the most wide-spread and abundant apteronotid electric fish species in the Amazon basin (Lundberg et al., 2013). Gut-content analysis indicates that $S$. calhamazon is the only Sternarchella known to feed on planktonic organisms as a mature adult. Stacked scales of other fishes in the absence of other fish tissue were also recovered in the stomach contents of specimens examined.
Small body size of Sternarchella calhamazon. Sternarchella calhamazon has the smallest body size among congeners, and exhibits several derived traits associated with small adult body size (max. $145 \mathrm{~mm}$ LEA vs. max. $291 \mathrm{~mm}$ LEA in S. orthos, and larger max. sizes in other congeners). These traits include lower pre-caudal vertebrae and anal-fin ray counts (Tab. 4). Small body size may have arisen from paedomorphosis; i.e. truncation of the ancestral ontogeny (Alberch et al., 1979), including neurocranial shape with a shorter face (pre-orbital region, Fig. 2), and an hour-glass shaped second basibranchial bone (Fig. 3) (shared with S. patriciae). In S. orthos and $S$. schotti, the second basibranchial initially ossifies with an hour-glass shape in juveniles, and becomes more ossified during growth to become fan or cylinder-shape in adults. Furthermore, as compared with congeners, S. calhamazon exhibits a more lightly ossified neurocranium and bony elements of the branchial basket.

Material examined. Holotype. INPA 37898, $162.8 \mathrm{~mm}$ TL male, Brazil, Amazonas State, rio Madeira, $35 \mathrm{~km}$ above confluence with rio Amazonas, collected with $3 \mathrm{~m}$ bottom trawl in channel 14-16 m deep, $400 \mathrm{~m}$ off linear beach and bank, $3^{\circ} 35^{\prime} 44.2^{\prime \prime} \mathrm{S}$ 58 57'45.8'W, 6 Aug 1996, Zanata et al. Field no. AMZ-96139. Non-types. Sternarchella calhamazon: USNM 373113, 8 (1 C\&S), 106-139 mm LEA, Brazil, rio Madeira, USNM 375362, 6, 91-125 mm LEA, Brazil, rio Içá 9 km below Bretania. USNM 373093, 3, 87-138 mm LEA, Brazil, rio Amazonas $11.5 \mathrm{~km}$ below Novo Oriente. IDSM 496, 1, 132 mm TL, Brazil, rio Japurá, near Boca do Lago Mamirauá, 0307.02'S 64²46.91'W, 19 Jan 1999, W. G. R. Crampton. INPA 15796, 11, 109-171 mm TL, Brazil, Mamirauá Lake System, Paraná Maiana station A, 0306.74'S 64ํำ.53’W, 2 Feb 1999. INPA 18151, 1, 138 mm TL, Brazil, rio Japurá, West bank, between Boca do Lago Mamirauá and Boca do Paraná do Jaquiri, $03^{\circ} 07.58^{\prime} \mathrm{S} 64^{\circ} 47.30^{\prime} \mathrm{W}, 9$ Feb 1999. INPA $18152,5,110-146 \mathrm{~mm}$ TL, Brazil, rio Solimões, South bank of Ilha do Jaquiri, $03^{\circ} 09.51^{\prime} \mathrm{S} 64^{\circ} 48.76^{\prime} \mathrm{W}, 9$ Dec 1999. MCP 49414, 1, 79 mm TL, Brazil, Mamirauá Lake System, Lago Promessa, 0304'23”'S 6446'52”W, 19 May 1998. MCP 49415, 9, 106-158 mm TL, Brazil, Mamirauá Lake System, Paraná Maiana station A, 0306'44"S 6447'32”W, 2 Feb 1999. MCP 49416, 1, 139 mm TL, Brazil, rio Japurá, West bank at Boca do Lago Mamirauá, 0307'36”'S 6446'15’W, 4 Feb 1999. MCP 49417, 3, 125-138 $\mathrm{mm}$ TL, Brazil, rio Solimões, South bank of Ilha do Jaquiri, 0309'31"S 6448'46”W, 9 Dec 1999. MCP 49418, 7, 89-140 mm TL, Brazil, Mamirauá Lake System, Paraná Maiana station B, 0304'50"S 64'47'18”'W, 11 Jan 2000. MCP 49419, 1, 96 mm TL, Brazil, Mamirauá Lake System, Paraná Maiana station A, 0306'44”S 6447'32”W, 23 Jan 2000. MCP 49420, 5, 111-140 $\mathrm{mm}$ TL, Brazil, rio Japurá-Solimões confluence, Praia Caborini, 0309'08"S 6447’04”W, 19 Feb 2001. MCP 49421, 1, 135 mm TL, Brazil, rio Solimões near Alvaraes, $03^{\circ} 13^{\prime} 06^{\prime \prime} \mathrm{S} 64^{\circ} 47^{\prime} 01^{\prime \prime} \mathrm{W}$, 27 Jan 2001. ANSP 200258, 123, (2 C\&S), 62-170 mm LEA, Peru, Río Amazonas, braid off right bank of main channel ca. 6 $\mathrm{km}$ northeast (downstream) of mouth of Río Nanay $03^{\circ} 39.621 \mathrm{~S}$ 073ํำ.278 W, 21 Sep 2015. 


\section{Sternarchella duccis (Lundberg, Cox Fernandes \& Albert, 1996)}

Fig. 16, Tab. 5

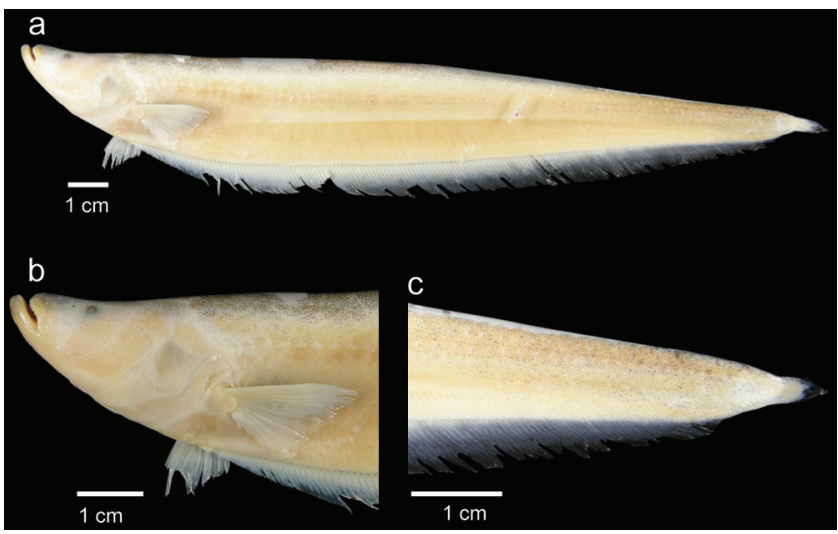

Fig. 16. Sternarchella duccis (ANSP 200514). a. Lateral view of the body, b. Lateral view of the head, c. Lateral view of the caudal region. Scale bars $=1 \mathrm{~cm}$.

Tab. 5. Morphometrics and meristic measurements for Sternarchella duccis.

\begin{tabular}{|c|c|c|c|c|}
\hline Characters & Minimum & Maximum & Mean & $\mathrm{n}$ \\
\hline LEA (mm) & 209.0 & 266.0 & 226.0 & 4 \\
\hline AFL & 179.0 & 194.0 & 184.7 & 4 \\
\hline HD1 & 13.4 & 14.6 & 14.2 & 4 \\
\hline HD2 & 21.3 & 23.7 & 22.5 & 4 \\
\hline $\mathrm{HL}$ & 29.0 & 33.0 & 30.6 & 4 \\
\hline PR & 8.1 & 9.8 & 9.4 & 4 \\
\hline $\mathrm{PO}$ & 19.8 & 20.7 & 20.3 & 4 \\
\hline ED & 1.9 & 2.1 & 20.3 & 4 \\
\hline IO & 4.3 & 4.5 & 4.4 & 4 \\
\hline HW & 11.9 & 12.4 & 12.2 & 4 \\
\hline MW & 7.1 & 7.3 & 7.2 & 4 \\
\hline PA & 10.7 & 10.7 & 14.6 & 4 \\
\hline CPD & $\mathrm{N} / \mathrm{A}$ & $\mathrm{N} / \mathrm{A}$ & $\mathrm{N} / \mathrm{A}$ & 0 \\
\hline CPL & $\mathrm{N} / \mathrm{A}$ & $\mathrm{N} / \mathrm{A}$ & $\mathrm{N} / \mathrm{A}$ & 1 \\
\hline AFR & 168 & 184 & 176 & 4 \\
\hline Unbranched AFR & 11 & 16 & 13.7 & 4 \\
\hline Pre-caudal vertebrae & 16 & 16 & - & 3 \\
\hline \multicolumn{5}{|c|}{ Percent HL } \\
\hline $\mathrm{PR} \%$ & 28.4 & 32.2 & 30.7 & 4 \\
\hline $\mathrm{PO} \%$ & 62.1 & 71.4 & 66.5 & 4 \\
\hline $\mathrm{ED} \%$ & 6.0 & 7.1 & 6.5 & 4 \\
\hline $\mathrm{IO} \%$ & 13.5 & 15.5 & 14.5 & 4 \\
\hline HW\% & 36.9 & 41.7 & 39.8 & 4 \\
\hline MW\% & 21.5 & 25.1 & 23.6 & 4 \\
\hline $\mathrm{PA} \%$ & 36.7 & 59.1 & 47.2 & 4 \\
\hline $\mathrm{CPD} \%$ & 0.0 & 0.0 & 0.0 & 0 \\
\hline $\mathrm{CPL} \%$ & 0.0 & 0.0 & 0.0 & 0 \\
\hline $\mathrm{CPD} / \mathrm{CPL}$ & 0.0 & 0.0 & 0.0 & 0 \\
\hline HL/LEA & 11.7 & 15.3 & 13.7 & 4 \\
\hline LEA/CPD & 0.0 & 0.0 & 0.0 & 0 \\
\hline $\mathrm{PR} / \mathrm{PO}$ & 45.0 & 48.4 & 46.1 & 4 \\
\hline
\end{tabular}

Magosternarchus duccis Lundberg et al., 1996:664, fig. 2 [type locality: Roraima, Brazil, rio Branco, 3-11 km upriver from confluence with rio Negro, $1^{\circ} 17^{\prime} \mathrm{S} 61^{\circ} 51^{\prime} \mathrm{W}$, collected using a $3 \mathrm{~m}$ bottom trawl at 6-7 m depth, 8 Dec 1993, J. Lundberg et al.]. -Crampton, 2007:311: fig. 11.6 [type locality: Brazil, Amazonas, Tefé].

Sternarchella duccis Ferraris et al., 2017:11 [species list].

Diagnosis. Sternarchella duccis can be diagnosed from all congeners by the presence of a highly superior mouth with the lower jaw projecting upwards beyond the upper jaw (vs. terminal in S. calhamazon, S. orthos, S. patriciae, S. raptor, $S$. rex, and $S$. schotti and sub-terminal in $S$. orinoco and $S$. sima) and a strongly concave dorsal margin of the frontal (vs. straight in S. calhamazon, S. orthos (western Amazon), $S$. patriciae, S. raptor, S. rex, and S. schotti and convex in $S$. orinoco and S. sima) (shared with Eastern Amazonian populations of $S$. orthos).

Description. Medium sized species of Sternarchella reaching an LEA of $266 \mathrm{~mm}$. Pectoral fin size small, less than $80 \%$ HL. PA\% Moderate, $37-59 \%$ HL. Head width narrow, distance between lateral margins $37-42 \%$ HL. Preorbital (snout) length moderate, $28-32 \%$ HL. Postorbital distance small, 62-71\% HL. Eye diameter small, 6-7\% HL. Interorbital distance small, 14-15\% HL. Mouth wide, distance between ricti $21-25 \%$ HL. Body depth less than HL. Scales absent on posterolateral portion of body. Scales large in size with 5-8 present above lateral line at mid-body. Scales dorsal to lateral line rhomboid at midbody. Rictus extends to a vertical with mental symphysis, gape short, more than three times eye diameter. Oral aperture superior, lower jaw extends anteriorly to upper jaw. Body cavity long 16 pre-caudal vertebrae present. Proximal surface of first displaced hemal spine narrower then descending blade. One to two displaced hemal spines present. Swim bladder not extending posterior to body cavity. Anal-fin pterygiophore length equal to or shorter than hemal spines. Anal-fin proximal small, shorter than hemal spine. One row of intermuscular bones visible externally in caudal peduncle. Premaxilla large, lateral margin of premaxilla longer than lateral margin of maxilla. Premaxilla triangular in ventral view. Two rows of teeth present on premaxilla. Anterior hook of maxilla absent, anterior process broad and triangular with a continuous ventral margin with descending blade. Anterior process of maxilla extending as a shelf of bone less than onethird length of descending blade. Ventral margin of maxillary blade curves evenly towards its distal tip. Descending blade maxilla thin, evenly curved. Two rows of teeth present on dentary. Dentary longer than deep, oral margin of dentary longer than length of angular articular. Dorsal margin of dentary slightly concave in lateral view. Endopterygoid process oblique (greater than $90^{\circ}$ to with dorsal surface of endopterygoid). Hyomandibula short, its width half its length. Dorsal margin of opercle 
concave. Opercle broad, width over half depth. Anterior limb of cleithrum length greater than ascending limb length. Post-temporal fused with supracleithrum in mature specimens. Ventral ethmoid large and robust with a large fan shaped lateral process. Dorso-anterior portion of mesethmoid straight. Anterior tip of mesethmoid scyphate on dorsal surface. Posterior fontanel longer than anterior fontanel. Lateral ethmoid robust and large, may contact ventral portion on frontals, hour-glass shaped with most narrow portion at mid-length. Orbitosphenoid broad, well ossified in median nasal septum with ventral margin longer than dorsal margin. Dorso-medial portion of orbitosphenoids in contact (visible through anterior fontanel in dorsal view). Absence of ventral process of pterosphenoid, anterior ventral margin of pterosphenoid similar to posterior ventral margin of orbitosphenoids. Lateral process of parasphenoid small, lateral margins of parasphenoid not extending to a horizontal with trigeminal foramen. Parasphenoid ventral margin straight or slightly curved. Distance between parietal ridges narrow, just lateral to supraoccipital, parietal ridges are very large and pronounced. No thorny projections present at border of parietal and supraoccipital. Dorsal margin of supraoccipital crest extends beyond dorsal margin of parietals. Supraoccipital crest extends to a dorsal distal tip. Internal carotid foramen reduced. Ventral surface of basioccipital smooth. Anterior extension of infraorbital canal short. Supraorbital canal fused to frontal. Mandibular canal size small. Mandibular canal ossicles form long slender tubes. Supratemporal laterosensory canal curved at a sharp angle on surface of parietal, extending posteriorly onto epaxial surface of body, terminal canal pore oriented posteriorly, epidermis overlying supratemporal canal depigmented. Endopterygoid large, contacting frontal. Base of gill rakers contacting gill arch. Gill rakers long with ossified distal tips. Dorsal surface of basihyal flat; small ridge may be present posteriorly. Second basibranchial hourglass shaped with narrowest portion at mid-length. Third basibranchial unossified. Twelve or less teeth present on pharyngobranchial. Eight or more teeth present on sixth hypobranchial. Medial surface of fourth hypobranchial with a process or bridge extending to meet contralateral process on midline. Urohyal blade unossified. First hypohyal bell-or cylinder shaped.

Coloration in alcohol. Yellowish white color, with a light brown mid-dorsum along the length of the body.

Sexual dimorphism. No sexual dimorphism found in 2 male and 2 female specimens.

Distribution and habitat. (Fig. 17). Distributed throughout the Amazon basin, where it inhabits deep river channels, collected at low densities. Gut-content analysis indicates that $S$. duccis feeds entirely on the tails and scales of other electric fishes.

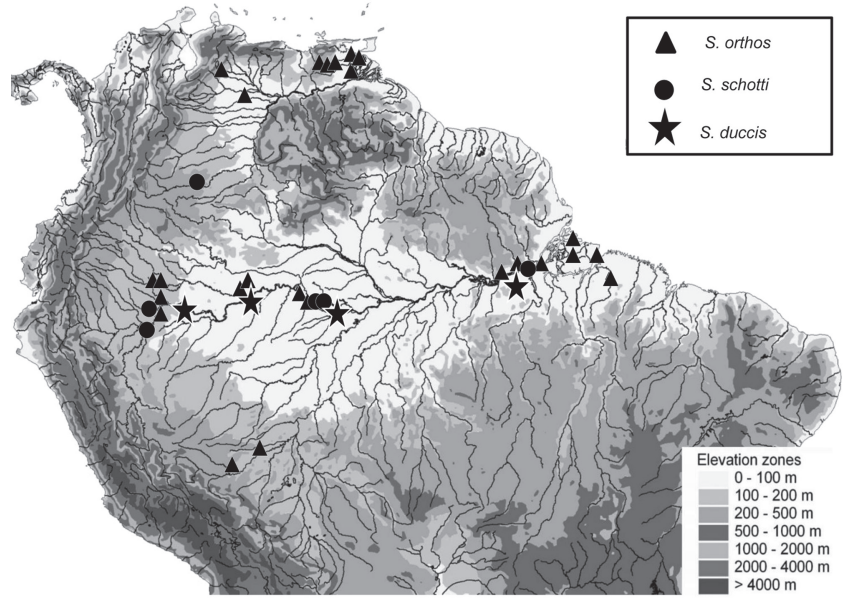

Fig. 17. Map of collection localities of $S$. orthos (triangles), $S$. schotti (circles), and $S$. duccis (stars). Note these three species are broadly sympatric throughout the Eastern and Western Amazon, with $S$. orthos also present in the upper Madeira and Lower Orinoco, and S. schotti known from a single specimen in the Meta River, Orinoco basin. Note also, S. orthos is represented at more sites than S. schotti.

Remarks. Sternarchella duccis possesses robust oral and pharyngeal dentition, which presumably aid in its predatory feeding habits.

Material examined. ANSP 200270, 2, 81-85 mm LEA, Peru, Iquitos, Loreto, Río Nanay, near confluence with Río Amazonas, 0341'32.9”S 73¹4’32.6”W, 17 Aug 2015, K. Evans. UF 116561, 1, 215 mm LEA, Iquitos, Loreto, Río Amazonas, 28 Mar 2001, J. Albert, W. Crampton. ANSP 200514, 3, 209-266 mm LEA, Iquitos, Loreto, Río Amazonas, 0342'72”S 73¹3'95.2”W, 26 Aug 2016, K. Evans. ANSP 192995 (1 C\&S), Brazil, Amazonas, rio Solimões,

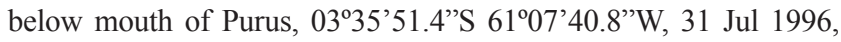
A. Zanata et al. USNM 337449 (2), Brazil, Roraima, rio Branco, 3-11 km upriver from confluence with rio Negro, $10^{\circ} 16^{\prime} 36^{\prime \prime} \mathrm{S}$ 6150'20’W, 8 Dec 1993, J. Lundberg et al.

\section{Sternarchella orinoco Mago-Leccia, 1994}

Fig. 18, Tab. 6

Sternarchella orinoco Mago-Leccia, 1994:189, figs. 94A, B and 95 [type locality: Venezuela, Río Orinoco between $\mathrm{km} 153$ and 152 in front of Isla Iguana, Território Delta Amacuro].

Diagnosis. Sternarchella orinoco can be diagnosed from all congeners by possession of a sub-terminal mouth (vs. terminal or superior in S. calhamazon, S. duccis, $S$. orinoco, $S$. orthos, S. raptor, S. rex, and S. schotti) (shared with $S$. sima), the possession of a small interorbital distance, $17-21 \%$ HL (vs. 19-25\% HL in S. sima) (shared with $S$. calhamazon and S. patriciae) and the presence of a long tail (CPL length more than HL) (vs. 23-93\% HL in all other Sternarchella species). 


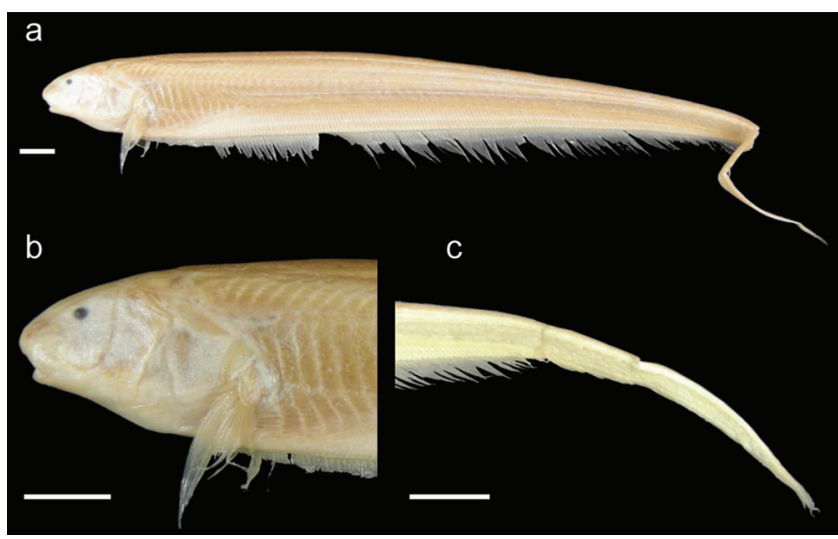

Fig. 18. Sternarchella orinoco (USNM 228727). a. Lateral view of the body, b. Lateral view of the head, c. Lateral view of the caudal region showing a single row of intermuscular bones in the caudal peduncle and the discontinuous caudal peduncle membrane. Scale bars $=1 \mathrm{~cm}$.

Tab. 6. Morphometrics and meristic measurements for Sternarchella orinoco.

\begin{tabular}{lcccc}
\hline Characters & Minimum & Maximum & Mean & $\mathrm{n}$ \\
\hline LEA (mm) & 170.0 & 220.0 & 196.4 & 7 \\
AFL & 104.0 & 190.0 & 161.9 & 7 \\
HD1 & 12.3 & 15.3 & 13.5 & 7 \\
HD2 & 16.7 & 21.5 & 18.9 & 7 \\
HL & 24.4 & 31.5 & 27.5 & 7 \\
PR & 7.2 & 9.5 & 8.0 & 7 \\
PO & 16.3 & 21.9 & 19.1 & 7 \\
ED & 1.3 & 1.9 & 1.7 & 7 \\
IO & 4.6 & 5.7 & 5.1 & 7 \\
HW & 10.1 & 15.1 & 11.2 & 7 \\
MW & 4.2 & 5.8 & 4.8 & 7 \\
PA & 8.8 & 13.5 & 11.8 & 7 \\
CPD & 4.09 & 6.9 & 5.1 & 6 \\
CPL & 33.2 & 38.2 & 36.0 & 3 \\
AFR & 184 & 206 & 194 & 7 \\
Unbranched AFR & 19 & 42 & 32 & 7 \\
Pre-caudal vertebrae & 15 & 16 & - & 4 \\
& Percent HL & & & \\
PR\% & 26.2 & 32.0 & 29.2 & 5 \\
PO\% & 65.9 & 74.8 & 69.4 & 7 \\
ED\% & 4.8 & 7.1 & 6.2 & 7 \\
IO\% & 16.7 & 20.6 & 18.7 & 7 \\
HW\% & 36.6 & 48.1 & 40.7 & 7 \\
MW\% & 15.4 & 19.8 & 17.3 & 7 \\
PA\% & 31.8 & 55.6 & 43.2 & 7 \\
CPD\% & 14.8 & 25.2 & 18.6 & 6 \\
CPL\% & 116.2 & 138.1 & 130.2 & 3 \\
CPD/CPL & 13.1 & 14.3 & 13.6 & 3 \\
HL/LEA & 12.8 & 16.2 & 14.0 & 7 \\
LEA/CPD & 2.36 & 3.5 & 2.6 & 6 \\
PR/PO & 37.0 & 39.8 & 42.1 & 7 \\
\hline & & & &
\end{tabular}

Description. Pectoral fin size large, $80 \%$ HL or greater. PA\% small, 32-56\% HL. Head wide, distance between lateral margins $37-48 \%$ HL. Preorbital (snout) length moderate, $26-32 \%$ HL. Postorbital distance large $66-75 \%$ HL. Eye diameter small, 5-7\% HL. Interorbital distance small, $17-21 \%$ HL. Mouth narrow, distance between ricti $15-20 \%$ HL. Body depth less than HL. Body color, yellowish gray. Scales absent on posterolateral portion of body. Scales large in size with 5-8 present above lateral line at mid-body. Scales dorsal to lateral line rhomboid at mid-body. Rictus extends to a vertical with mental symphysis, gape very small, less than twice eye diameter. Oral aperture sub-terminal, upper jaw extends anteriorly to lower jaw. Body cavity long; 15-16 pre-caudal vertebrae. Proximal surface of first displaced hemal spine narrower then descending blade. One to two displaced hemal spines present. Swim bladder not extending posterior to body cavity. Anal-fin pterygiophore length equal to or shorter than hemal spines. Anal-fin proximal length, shorter than hemal spine. One row of bones in caudal peduncle visible externally. Caudal peduncle shallow 15-25\% HL. Dark spot on caudal peduncle absent. No apparent connective tissue between anal-fin base and caudal peduncle. Tail long, caudal peduncle length greater than HL. Premaxilla large, lateral margin of premaxilla longer than lateral margin of maxilla. Premaxilla square in ventral view. Four rows of teeth present on premaxilla. Anterior hook of maxilla absent, anterior process broad and triangular with a continuous ventral margin with descending blade. Anterior process of maxilla extending as a shelf of bone less than one-third length of descending blade. Ventral margin of maxillary blade curves evenly towards its distal tip. Descending blade maxilla thin, evenly curved. Three to four rows of teeth present on dentary. Dentary longer than deep, oral margin of dentary longer than length of angular articular. Dorsal margin of dentary slightly concave in lateral view. Posterior margin of dentary curves gradually to descending limb. Endopterygoid large, contacting frontal. Angle of endopterygoid process with dorsal margin of endopterygoid oblique (greater than $90^{\circ}$ with dorsal surface of endopterygoid). Hyomandibula short, its width half its length. Dorsal margin of opercle concave. Opercle broad, width over half depth. Anterior limb of cleithrum length greater than ascending limb length. Post-temporal fused with supracleithrum in mature specimens. Ventral ethmoid large and robust with a large fan shaped lateral process. Dorso-anterior portion of mesethmoid strongly curved from anterior tip to frontal boundary. Anterior tip of mesethmoid convex and rounded. Anterior fontanel longer than posterior fontanel. Lateral ethmoid large hour-glass shaped, most narrow portion at mid-length. Orbitosphenoid broad, well-ossified in median nasal septum with ventral margin longer than dorsal margin. Dorso-medial portion of orbitosphenoids in contact (visible through anterior fontanel in dorsal view). Absence of ventral process of 
pterosphenoid, anterior ventral margin of pterosphenoid similar to posterior ventral margin of orbitosphenoids. Lateral process of parasphenoid small, lateral margins of parasphenoid not extending to a horizontal with trigeminal foramen. Parasphenoid ventral margin straight or slightly curved. Narrow, just lateral to supraoccipital, parietal ridges are very large and pronounced. No crown of thorny projections present at border of parietals and supraoccipital. Dorsal margin of supraoccipital crest exceed dorsal margin of parietals. Supraoccipital crest extends to a dorsal distal tip. Internal carotid foramen. Ventral surface of basioccipital smooth. Anterior extension of infraorbital canal short. Supraorbital canal fused to frontal. Mandibular canal size small. Mandibular canal ossicles form long slender tubes. Supratemporal laterosensory canal curved at a sharp angle on surface of parietal, extending posterior onto epaxial surface of body, terminal canal pore oriented posteriorly, epidermis overlying supratemporal canal depigmented. Base of gill rakers contacting gill arch. Gill rakers long with ossified distal tips. Dorsal surface of basihyal convex forming a robust ridge posteriorly. Second basibranchial triangular with short stem (length of descending rod less dorsal margin). Third basibranchial unossified. Fourteen or more teeth present on pharyngobranchial. Eight or more teeth present on sixth hypobranchial. Medial surface of fourth hypobranchial with a process or bridge extending to meet contralateral process on midline. Urohyal blade unossified. First hypohyal triangular, base longer than any other margin of the same bone.

Coloration in alcohol. Yellowish brown color, with striations demarcating the ribs at the body cavity.

Sexual dimorphism. Mature female specimens of S. orinoco have wider heads than male specimens of comparable sizes (Mago-Leccia, 1994).

Distribution and habitats. (Fig. 19). This species is known only from the Orinoco River basin, where it is inhabits deep river channels. It has been most commonly collected in the Amacuro estuary and Llanos floodplains.

Remarks. While superficially resembling $S$. sima, this species possesses several differences including tail length, gill raker condition (contacting gill arch vs. non-contacting in $S$. sima), a straight ventral profile, and skull width. Females have a wider head and a deeper body (MagoLeccia, 1994:99).

Material examined. Holotype. MBUCV-V-10514, 1, $201 \mathrm{~mm}$. TL, Venezuela, Río Orinoco, between km 153 and 152 in front of Isla Iguana, Território Delta Amacuro, collected by J. G. Lundberg, 18 Feb 1978. Non-types. Venezuela: USNM 228727, 8, (3 C\&S) 189-221 mm LEA, Venezuela, Delta Amacuro, Río Orinoco, Old Shipping Channel of Isla Portuguesa.

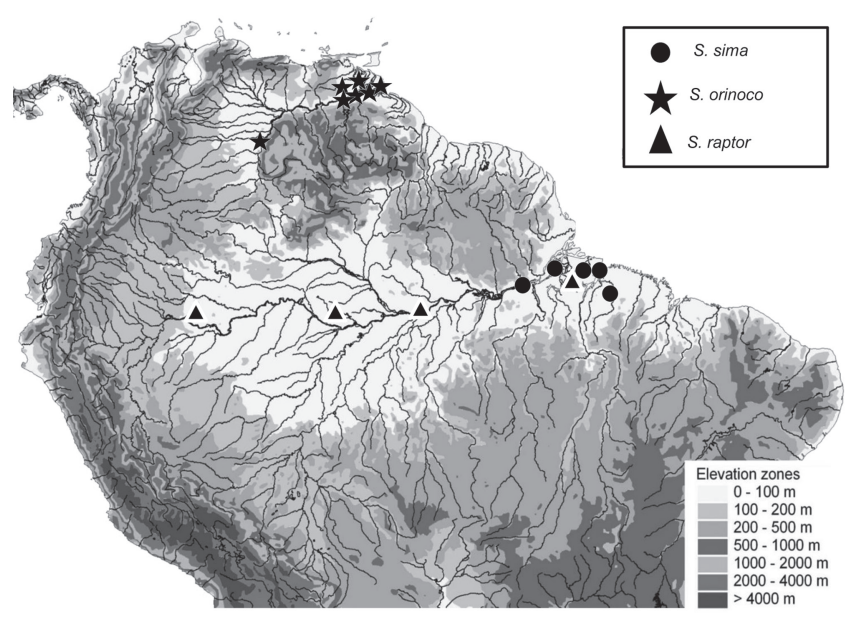

Fig. 19. Map of collection localities for specimens in the $S$. sima group. Sternarchella sima (circles), S. orinoco (stars), and $S$. raptor (triangles). Note most specimens of the $S$. sima group have been collected near the mouths of the Amazon and Orinoco rivers.

\section{Sternarchella orthos Mago-Leccia, 1994}

Fig. 20, Tab. 7

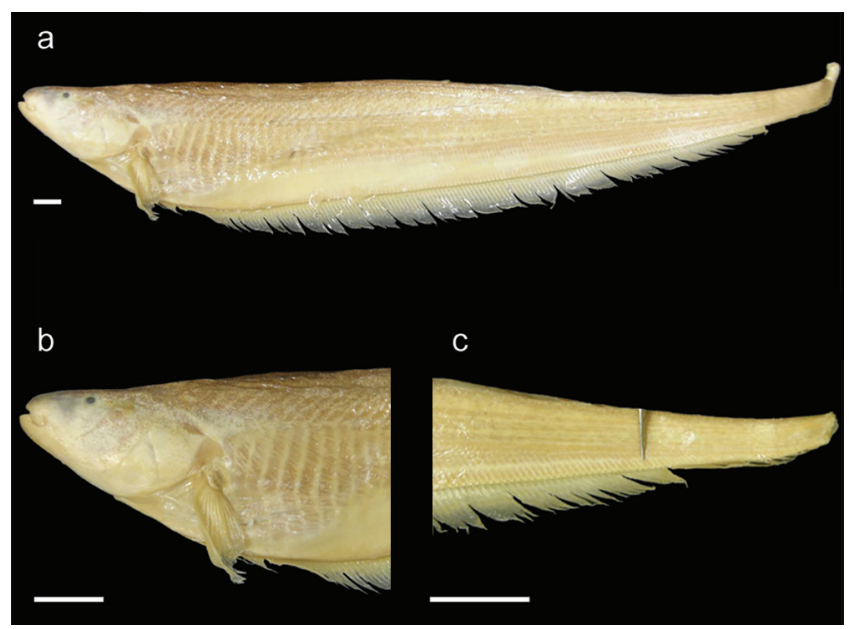

Fig. 20. Sternarchella orthos (USNM 228871). a. Lateral view of the body, b. Lateral view of the head, c. Lateral view of the caudal region showing a single row of intermuscular bones in the caudal peduncle, and the discontinuous caudal peduncle membrane. Scale bars $=1 \mathrm{~cm}$.

Sternarchella orthos Mago-Leccia, 1994:188, fig. 93: tab. 5 [type Locality: Venezuela, Río Apure, near, Apure].

Sternarchella cf. terminalis. -Lundberg, 2013:163, fig. 5C [type locality: Brazil, rio Amazonas, above rio Tapajos].

Sternarchella terminalis. -Ivanyisky, Albert, 2014:569, fig. 2 [type locality: Peru, Madre de Dios, Río Los Amigos]. -Crampton, Albert, 2006:386 [Brazil, rio Amazonas near Tefé]. -Crampton, 2007:316, fig. 11.6 3E [Brazil, rio Amazonas near Tefé]. -Crampton, 2011:165-189 [Brazil, rio Amazonas near Tefé]. 
Tab. 7. Morphometrics and meristic measurements for Sternarchella orthos.

\begin{tabular}{|c|c|c|c|c|}
\hline Characters & Minimum & Maximum & Mean & $\mathrm{n}$ \\
\hline LEA (mm) & 203.0 & 301.0 & 242.5 & 36 \\
\hline AFL & 174.0 & 268.0 & 208.4 & 36 \\
\hline HD1 & 14.7 & 21.1 & 17.7 & 36 \\
\hline HD2 & 22.2 & 32.9 & 26.5 & 36 \\
\hline HL & 33.9 & 46.7 & 40.4 & 36 \\
\hline PR & 9.8 & 14.1 & 12.1 & 36 \\
\hline $\mathrm{PO}$ & 23.00 & 31.6 & 27.4 & 36 \\
\hline ED & 1.7 & 3.1 & 2.2 & 36 \\
\hline IO & 4.6 & 7.8 & 6.0 & 36 \\
\hline HW & 12.7 & 20.0 & 16.6 & 36 \\
\hline MW & 5.4 & 17.9 & 7.7 & 36 \\
\hline PA & 11.5 & 26.7 & 18.7 & 36 \\
\hline $\mathrm{CPD}$ & 2.9 & 9.0 & 5.0 & 17 \\
\hline CPL & 9.1 & 45.6 & 24.2 & 17 \\
\hline AFR & 157.0 & 205.0 & 184.0 & 36 \\
\hline Unbranched AFR & 16 & 44 & 27 & 36 \\
\hline Pre-caudal vertebrae & 14 & 15 & - & 21 \\
\hline \multicolumn{5}{|c|}{ Percent HL } \\
\hline $\mathrm{PR} \%$ & 27.8 & 32.3 & 30.0 & 36 \\
\hline $\mathrm{PO} \%$ & 63.1 & 70.4 & 67.1 & 36 \\
\hline $\mathrm{ED} \%$ & 4.2 & 6.8 & 5.6 & 36 \\
\hline $\mathrm{IO} \%$ & 12.3 & 18.4 & 15.4 & 36 \\
\hline HW\% & 36.0 & 56.9 & 43.8 & 36 \\
\hline MW\% & 14.6 & 41.6 & 18.6 & 36 \\
\hline $\mathrm{PA} \%$ & 33.9 & 70.6 & 48.4 & 36 \\
\hline $\mathrm{CPD} \%$ & 8.2 & 22.2 & 13.6 & 17 \\
\hline CPL\% & 10.2 & 22.2 & 53.0 & 17 \\
\hline $\mathrm{CPD} / \mathrm{CPL}$ & 11.3 & 156.1 & 37.1 & 17 \\
\hline HL/LEA & 13.5 & 18.4 & 16.2 & 36 \\
\hline LEA/CPD & 1.3 & 3.9 & 2.1 & 17 \\
\hline $\mathrm{PR} / \mathrm{PO}$ & 40.9 & 49.3 & 44.8 & 36 \\
\hline
\end{tabular}

Diagnosis. Sternarchella orthos can be diagnosed from all congeners by the presence of a terminal mouth ( $v s$. sub-terminal in $S$. orinoco and $S$. sima, and superior in S. calhamazon, S. duccis and S. patriciae) (shared with $S$. raptor, $S$. rex, and $S$. schotti) the possession of a long body cavity with 14-16 pre-caudal vertebrae (vs. less than 14 in $S$. calhamazon) (shared with $S$. duccis, S. orinoco, S. patriciae, S. raptor, S. rex, S. schotti, and $S$. sima), the presence of a fan or rod-shaped second basibranchial (vs. hour-glass shaped in S. calhamazon, $S$. duccis, $S$. patriciae, $S$. raptor, and $S$. rex and triangular in $S$. sima and S. orinoco) (shared with $S$. schotti) and the presence of a crown of thorny projections present at border between parietals and supraoccipital, continuing to epioccipital (vs. no crown present in $S$. calhamazon, S. duccis, S. orinoco, S. raptor, S. rex, S. schotti, and $S$. sima) (shared with $S$. patriciae).
Description. Medium to large size species reaching $256 \mathrm{~mm}$ LEA. Pectoral fin size small, less than $80 \%$ HL. PA \% moderate, 46-49\% HL. Head narrow, distance between lateral margins $36-57 \%$. Preorbital (snout) length moderate, $28-32 \%$ HL. Postorbital distance small, $63-70 \%$ HL. Eye diameter small, 4-7\% HL. Interorbital distance small, 12-18\% HL. Mouth narrow, distance between ricti $15-41 \%$ HL. Body depth less than HL. Scales absent on posterolateral portion of body. Scales large in size with 5-8 present above lateral line at midbody. Scales dorsal to lateral line rhomboid at mid-body. Rictus extends to a vertical with mental symphysis, gape very small, less than twice eye diameter. Oral aperture terminal, upper and lower jaws equal in length. Body cavity long; 14-16 pre-caudal vertebrae present. Proximal surface of first displaced hemal spine narrower then descending blade. One to two displaced hemal spines. Swim bladder not extending posterior to body cavity. Anal-fin pterygiophore length equal to or shorter than hemal spines. Anal-fin proximal length shorter than hemal spine. One row of bones in caudal peduncle visible externally. Caudal peduncle shallow 8-22\% HL. Dark spot on caudal peduncle absent. No apparent connective tissue between anal-fin base and caudal peduncle. Caudal peduncle length less than HL. Premaxilla large, lateral margin of premaxilla longer than lateral margin of maxilla. Premaxilla triangular in ventral view. Three rows of teeth present on premaxilla. Anterior hook of maxilla absent, anterior process of maxilla broad and triangular with a continuous ventral margin with descending blade. Anterior process of maxilla extending as a shelf of bone less than one-third length of descending blade. Ventral margin of maxillary blade curves evenly towards its distal tip. Descending blade maxilla thin, evenly curved. Two rows of teeth present on dentary. Dentary longer than deep, oral margin of dentary longer than length of angular articular. Dorsal margin of dentary slightly concave in lateral view. Posterior margin of dentary curves gradually to descending limb. Ventral ethmoid large and robust with a large fan shaped lateral process. Dorso-anterior portion of mesethmoid straight. Anterior tip of mesethmoid scyphate on dorsal surface. Anterior fontanel longer than posterior fontanel. Lateral ethmoid very robust and large, may contact ventral portion on frontals, hour-glass shaped with most narrow portion at mid-length. Orbitosphenoid broad, well ossified in median nasal septum with ventral margin longer than dorsal margin. Dorso-medial portion of orbitosphenoids in contact (visible through anterior fontanel in dorsal view). Absence of ventral process of pterosphenoid, anterior ventral margin of pterosphenoid similar to posterior ventral margin of orbitosphenoids. Small, lateral margins of parasphenoid not extending to a horizontal with trigeminal foramen. Parasphenoid ventral margin straight or slightly curved. Narrow, just lateral to supraoccipital, parietal ridges are very large and pronounced. Crown 
of thorny projections present at border of parietals and supraoccipital, continuing to epioccipital. Dorsal margin of supraoccipital crest exceed dorsal margin of parietals. Supraoccipital crest extends to a dorsal distal tip. Internal carotid foramen reduced. Ventral surface of basioccipital smooth. Anterior extension of infraorbital canal shorter than width of canal pore, anterior canal pore of infraorbital near first infraorbital. Supraorbital canal fused to frontal. Mandibular canal size small. Mandibular canal ossicles form long slender tubes. Supratemporal laterosensory canal curved at a sharp angle on surface of parietal, extending posterior onto epaxial surface of body, terminal canal pore oriented posteriorly, epidermis overlying supratemporal canal depigmented. Endopterygoid process small, not contacting frontal. Endopterygoid process extends vertically at or near a $90^{\circ}$ with dorsal surface of endopterygoid. Hyomandibula short, its width half its length. Dorsal margin of opercle concave. Opercle broad, width over half depth. Base of gill rakers contacting gill arch. Gill rakers long with ossified distal tips. Dorsal surface of basihyal convex forming a robust ridge posteriorly. Second basibranchial fan-shaped, extending to long narrow end. Third basibranchial unossified. Fourteen or more teeth present on pharyngobranchial. Eight or more teeth present on sixth hypobranchial. Medial surface of fourth hypobranchial with a process or bridge extending to meet contralateral process on midline. Urohyal blade unossified. Anterior limb of cleithrum length greater than cleithrum ascending limb length. Post-temporal fused with supracleithrum in mature specimens. First hypohyal bell- or cylinder shaped.

Coloration in alcohol. Yellowish brown color, with striations demarcating the ribs at the body cavity. In life, this species is pale white in color with a pink hue (Fig. $12 d)$.

Sexual dimorphism. No sexual dimorphism found in 9 male and 11 female specimens.

Distribution and habitat. (Fig. 17). This species is widely distributed throughout the Amazon and Orinoco River basins.

Remarks. This species is highly variable throughout its range with narrower and longer individuals found in the Orinoco River basin, and deeper-bodied populations found in the Amazon basin (Fig. 21-22). This species is also highly variable in mouth position ranging from terminal in the Western Amazon to superior in the Eastern Amazon, as also observed by Lundberg et al. (2013).

In comparison to congeners, $S$. orthos exhibits a wide range of variation in head shape and body depth throughout its geographic range. Sternarchella orthos in the Eastern Amazon often possess a concave head and skull, resembling the head and skull shape of Sternarchella duccis (Lundberg et al., 1996). This morphology does not appear to be a secondary sexual phenotype of mature males or females (Lundberg et al., 2013; fig. 8). It is unclear if a concave head and skull is linked to trophic differences. In the Western Amazon, S. orthos exhibits a wider head, a straighter skull, deeper body, and larger body size than observed in populations from the Eastern Amazon. In the Orinoco basin, Sternarchella orthos exhibits a longer tail, a narrower head and a shallower body than populations from the Eastern and Western Amazon. No discrete osteological, or genetic differences are yet known between populations of $S$. orthos in the Amazon and Orinoco basins.

Craniofacial variation in Sternarchella orthos. Sternarchella orthos exhibits a wide range of craniofacial variation, from a slender head with a superior mouth to a deeper head with a terminal mouth (Figs. 21-22). Lundberg et al. (2013: fig. 8) concluded that these differences do not indicate species-level differences, as the variation is continuous and does not correlate to other morphological characters. Here we report similar findings in head shape using geometric morphometrics. We detected no discrete differences among three populations of $S$. orthos from the Western Amazon, Eastern Amazon and Orinoco basins (Fig. 22).

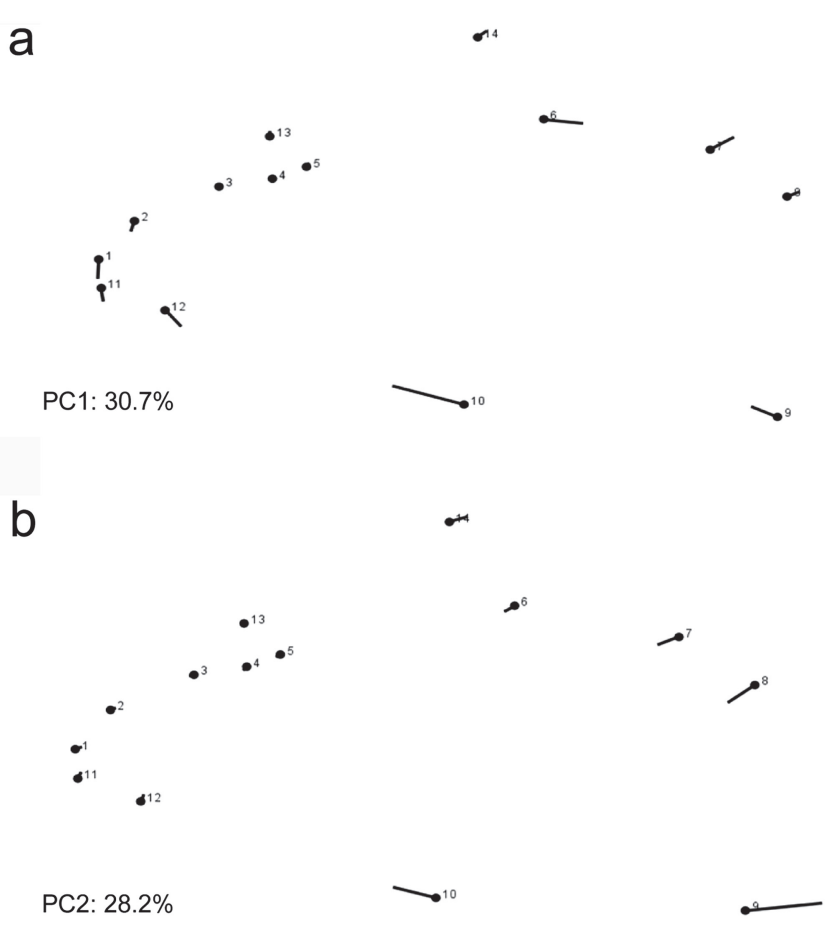

Fig. 21. Results of geometric morphometric analysis of Sternarchella orthos from river basins of northern South America. a. PC1 corresponds to variation in position of mouth, anus, and posterior head margin. b. PC2 corresponds to variation in opercle width, and position of anus and analfin origin. 


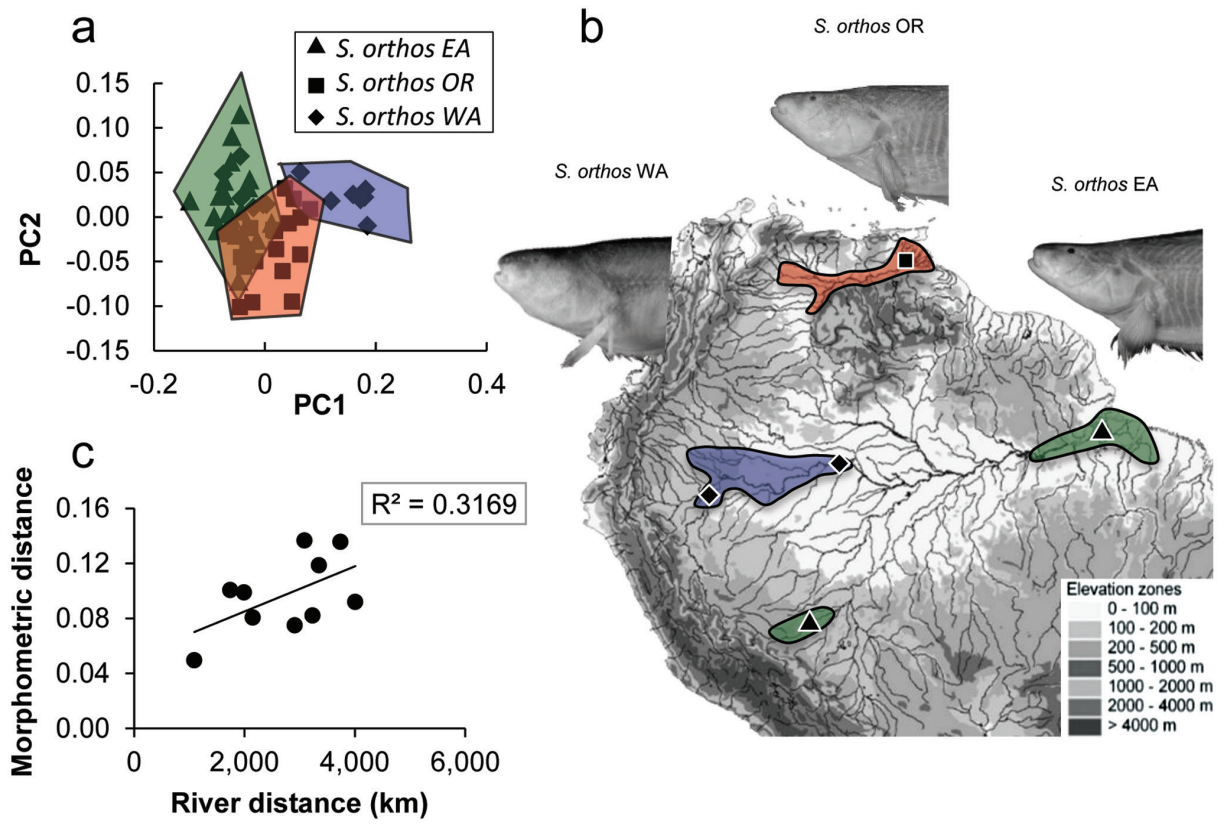

Fig. 22. Head-shape variation in Sternarchella orthos from three hydrogeographic regions of Greater Amazonia. a. Principal components analysis. Position of mouth, anus, and posterior head margin load heavily on PC1, and opercle width and position of anus and anal-fin on in PC2 (Fig. 7). EA, Eastern Amazon (green); OR, Orinoco (red); WA, Western Amazon (blue), upper Madeira included in EA on both morphometric and hydrogeographic grounds. Note the partial separations among the three populations. b. Geographic distributions and representative phenotypes of $S$. orthos in the three regions. c. Significant correlation $(p=0.045)$ between morphometric and river distance among five locations (symbols in panel B). Morphometric distances from CVA of head shape data; river distances as thalweg measured in Google Earth.

Material examined. Porotergus terminalis: CAS 54912, 1, Peru, Loreto, Iquitos, 1 Jan 1922, S. Morris. Sternarchella orthos: USNM 228839, 6, 229-256 mm LEA, Delta Amacuro, Río Orinoco, Old Shipping Channel S. of Isla Portuguesa, Venezuela. USNM 228725, (2 C\&S) Delta Amacuro, Río Orinoco, Old Shipping Channel S. of Isla Portuguesa, Venezuela. USNM 228840, 13, 176-259 mm LEA, Delta Amacuro, Río Orinoco, deep river channel near Los Castillos, 161 Nautical miles upstream from sea buoy, Venezuela. USNM 228871, 8, 235-301 mm LEA, Delta Amacuro, río Orinoco, deep river channel near Los Castillos, 162 Nautical miles upstream from sea buoy. "Sternarchella terminalis": Brazil: ANSP 199199, 5, 159-173 mm LEA, rio Amazonas below rio Xingu. FMNH 115236, 3, $122-$ 175 mm LEA, Pará, Brazil, rio Amazonas, between tributaries Furo de Urucuricaia and Paraná dos Arraiolos, between towns Almeirim and Gurupa. IDSM 495, 2, 110-110 mm TL, Mamirauá Lake System, Paraná Maiana station A, $2.5 \mathrm{~km} 045^{\circ}$ from Comunidade Boca do Mamirauá, 0306.74'S 6447.53’W, 9 Sep 1999. INPA 18265, 1, 252 mm TL, Mamirauá Lake System, Paraná Maiana station A, 0306.74'S 64²7.53’W, 28 Jan 1999. MCP 33370, 2, 79-93 mm TL, Mamirauá Lake System, Lago Promessa, 0304.38’S 6446.97’W, 19 May 1998. MCP 49432, 1, 155 mm TL, Mamirauá Lake System, Paraná Maiana station A, 0306'44”S 6447'32”W, 13 Jan 1999. MCP 49433, 2, 231-267 mm TL, Mamirauá Lake System, Paraná Maiana station C, 0304'06”S 6447’31'W, 5 Feb 1999. MCP 49435, 4, 125-246 mm TL, Río Japurá, West bank at Boca do Lago Mamirauá, 0307’36”S 6446’15'W, 3 Dec 1999. MCP 49436, 4, 160-250 mm TL, Río JapuráSolimões Confluence, Praia Caborini, 0309'08'S 6447'04'W, 19 Feb 2001. ZUEC 12340, 1, 262 mm, Mamirauá Lake System, Paraná
Maiana station B, $03^{\circ} 04.83^{\prime} \mathrm{S} 64^{\circ} 47.30^{\prime} \mathrm{W}, 25$ Jan 1999. ZUEC 12341, 1, 219 mm TL, Río Tefé, Toco Preto, 0347.31'S 6459.91'W, 22 Oct 1999. Peru: MUSM 45236, 2, Madre de Dios state, Río Madre de Dios $2 \mathrm{~km}$ upstream bridge at Puerto Maldonado. UF 238215, 1, $271 \mathrm{~mm}$ LEA, Peru, Isla Milagro beach, East bank Río Amazonas, upstream of Iquitos, $7.64 \mathrm{~km}$ and $21.86^{\circ}$ from Plaza de Armas.

\section{Sternarchella raptor (Lundberg, Cox Fernandes \& Albert, 1996)}

Fig. 23, Tab. 8

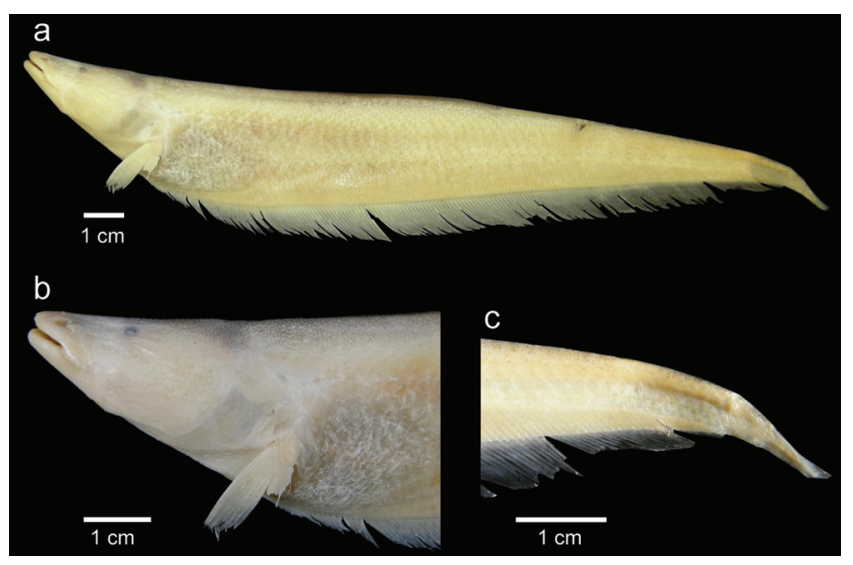

Fig. 23. Sternarchella raptor (ANSP 200511). a. Lateral view of the body, b. Lateral view of the head, c. Lateral view of the caudal region. Scale bars $=1 \mathrm{~cm}$. 
Tab. 8. Morphometrics and meristic measurements for Sternarchella raptor.

\begin{tabular}{lcccc}
\hline Characters & Minimum & Maximum & Mean & $\mathrm{n}$ \\
\hline LEA (mm) & 169.0 & 205.0 & 182.5 & 4 \\
AFL & 135.0 & 171.0 & 149.0 & 4 \\
HD1 & 11.1 & 13.8 & 12.1 & 4 \\
HD2 & 17.4 & 21.2 & 18.8 & 4 \\
HL & 32.8 & 39.3 & 35.1 & 4 \\
PR & 11.4 & 14.4 & 12.8 & 4 \\
PO & 19.2 & 25.0 & 21.3 & 4 \\
ED & 1.5 & 2.2 & 1.9 & 4 \\
IO & 3.4 & 4.8 & 4.0 & 4 \\
HW & 12.5 & 15.8 & 14.1 & 4 \\
MW & 6.7 & 9.8 & 8.3 & 4 \\
PA & 12.8 & 12.8 & 14.2 & 4 \\
CPD & 4.8 & 5.6 & 5.2 & 3 \\
CPL & 7.6 & 8.6 & 8.1 & 2 \\
AFR & 176 & 183 & 177.7 & 4 \\
Unbranched AFR & 15 & 17 & 15.5 & 4 \\
Pre-caudal vertebrae & 15 & 15 & - & 2 \\
& Percent HL & & & \\
PR\% & 34.9 & 37.7 & 36.5 & 4 \\
PO\% & 58.1 & 63.8 & 60.7 & 4 \\
ED\% & 4.2 & 6.8 & 5.6 & 4 \\
IO\% & 10.4 & 12.2 & 11.5 & 4 \\
HW\% & 38.2 & 41.3 & 40.0 & 4 \\
MW\% & 20.6 & 25.0 & 23.5 & 4 \\
PA\% & 38.9 & 41.8 & 40.4 & 4 \\
CPD\% & 14.2 & 15.1 & 14.6 & 3 \\
CPL\% & 21.8 & 25.8 & 23.8 & 2 \\
CPD/CPL & 56.5 & 69.4 & 62.9 & 2 \\
HL/LEA & 19.0 & 19.4 & 19.2 & 4 \\
LEA/CPD & 2.7 & 2.9 & 2.8 & 3 \\
PR/PO & 64.9 & 60.1 & 4 \\
\hline
\end{tabular}

Magosternarchus raptor Lundberg et al., 1996:658, fig. 1 [type locality: Amazonas, Brazil, río Solimões, $17 \mathrm{~km}$ downriver

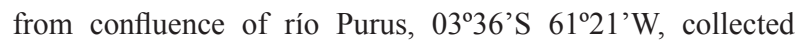
using a 3 x $1 \mathrm{~m}$ bottom trawl at 4-6 m depth, 29 Nov 1993, J. Lundberg et al.]. -Crampton, 2007:311, fig. 11.6 [type locality: Brazil, Amazonas, Tefé].

Sternarchella raptor Ferraris et al., 2017:11 [species list].

Diagnosis. Sternarchella raptor can be diagnosed from all congeners by the presence of a long snout, PR 35-38\% HL (vs. 24-32\%HL in all other Sternarchella species), eyes located near the dorsal margin of the head ( $v s$. eyes located on lateral margin of head in $S$. calhamazon, $S$. orthos, $S$. orinoco, S. patriciae, $S$. rex, S. schotti, and S. sima) (shared with $S$. duccis), a maxilla with an enlarged anterior process greater than one-third the length of the descending blade ( $v s$. reduced anterior process less than one-third the length of descending maxillary blade in all other Sternarchella species) and robust oral dentition usually visible externally in mature specimens (vs. obscured dentition in S. calhamazon, S. orthos, S. orinoco, S. patriciae, S. schotti, and S. sima) (shared with $S$. duccis and S. rex).
Description. Medium-sized species of Sternarchella, reaching $205 \mathrm{~mm}$ LEA. Pectoral fin size small, less than $80 \%$ HL. PA \% moderate, $39-42 \%$ HL. Head width narrow, distance between lateral margins 38-41\% HL. Preorbital (snout) length large, 35-38\% HL. Postorbital distance small, $58-64 \%$ HL. Eye diameter small, 4-7\% HL. Interorbital distance small, 10-12\% HL. Mouth wide, distance between ricti $21-25 \%$ HL. Body depth less than HL. Scales absent on posterolateral portion of body. Scales large in size with 5-8 present above lateral line at mid-body. Scales dorsal to lateral line rhomboid at mid-body. Rictus extends to a vertical with mental symphysis, gape short, more than three times eye diameter. Oral aperture terminal, upper and lower jaws equal in length. Body cavity long, 15 precaudal vertebrae. Proximal surface of first displaced hemal spine narrower then descending blade. One to two displaced hemal spines. Swim bladder not extending posterior to body cavity. Anal-fin pterygiophore length equal to or shorter than hemal spines. Anal-fin proximal small, shorter than hemal spine. One row of intermuscular bones visible externally in caudal peduncle. Caudal peduncle narrow, $14-15 \%$ HL. Dark spot on caudal peduncle absent. No apparent connective tissue between anal-fin base and caudal peduncle. Caudal peduncle length short, less than HL. Premaxilla large, lateral margin of premaxilla longer than lateral margin of maxilla. Premaxilla triangular in ventral view. Two rows of teeth present on premaxilla. Anterior hook of maxilla absent, anterior process broad and triangular with a continuous ventral margin with descending blade. Anterior process of maxilla large and broad, extending more than one half length of descending blade in mature specimens. Ventral margin of maxillary blade strait to distal tip. Two rows of teeth present on dentary. Dentary longer than deep, oral margin of dentary longer than length of angular articular. Dorsal margin of dentary slightly concave in lateral view. Endopterygoid process oblique (greater than $90^{\circ}$ with dorsal surface of endopterygoid). Hyomandibula short, its width half its length. Dorsal margin of opercle concave. Opercle broad, width over half depth. Anterior limb of cleithrum length greater than cleithrum ascending limb length. Post-temporal fused with supracleithrum in mature specimens. Ventral ethmoid large and robust with a large fan shaped lateral process. Dorso-anterior portion of mesethmoid strongly curved from anterior tip to frontal boundary. Anterior tip of mesethmoid scyphate on dorsal surface. Posterior fontanel longer than anterior fontanel. Lateral ethmoid very robust and large, may contact ventral portion on frontals, hour-glass shaped with most narrow portion at mid-length. Orbitosphenoid broad, well ossified in median nasal septum with ventral margin longer than dorsal margin. Dorso-medial portion of orbitosphenoids in contact (visible through anterior fontanel in dorsal view). Process originating from ventral portion of most anterior part of pterosphenoid present, sometimes contacting parasphenoid. Lateral process of parasphenoid small, lateral margins of parasphenoid not extending to a horizontal 
with trigeminal foramen. Parasphenoid ventral margin straight or slightly curved. Distance between parietal ridges narrow, just lateral to supraoccipital, parietal ridges are very large and pronounced. No thorny projections present at border of parietal and supraoccipital. Dorsal margin of supraoccipital crest extends beyond dorsal margin of parietals. Supraoccipital crest extends to a dorsal distal tip. Internal carotid foramen reduced. Ventral surface of basioccipital smooth. Anterior extension of infraorbital canal short. Supraorbital canal fused to frontal. Mandibular canal size small. Mandibular canal ossicles form long slender tubes. Supratemporal laterosensory canal curved at a sharp angle on surface of parietal, extending posterior onto epaxial surface of body, terminal canal pore oriented posteriorly, epidermis overlying supratemporal canal depigmented. Endopterygoid large, contacting frontal. Base of gill rakers contacting gill arch. Gill rakers long with ossified distal tips. Dorsal surface of basihyal flat, small ridge may be present posteriorly. Second basibranchial hour-glass shaped with most narrow portion at mid-length. Third basibranchial unossified. Twelve or less teeth present on pharyngobranchial. Eight or more teeth present on sixth hypobranchial. Medial surface of fourth hypobranchial with a process or bridge extending to meet contralateral process on midline. Urohyal blade unossified. First hypohyal bellor cylinder shaped.

Coloration in alcohol. Yellowish white color, with a light brown mid-dorsum along the length of the body.

Sexual dimorphism. No sexual dimorphism found in three male and one female specimens.

Distribution and habitat. Distributed throughout the Amazon basin, where it inhabits deep river channels. (Fig. 19). Sternarchella raptor is wide-spread in the Amazon basin, however it is often collected in low densities. Gutcontent analysis indicates that $S$. raptor feeds on the scales and tails of other electric fishes (based on the presence of stacked scales, vertebrae and cartilaginous regenerated caudal filament rods).

Remarks. Sternarchella raptor possesses robust oral and pharyngeal dentition which presumably aid in its predatory feeding habits. This species also possesses the longest snout of any Sternarchella.

Material examined. USNM 337448, 2, Brazil, Amazonas, rio Solimões, $6.2 \mathrm{~km}$ downriver from confluence with rio Purus, 26 Oct 1993, S. Jewett et al. UF 116762 (1 C\&S), Peru, Loreto, Río Amazonas, 28 Mar 2001, J. Albert and W. Crampton. ANSP 200266, 2, 107-185 mm LEA, Loreto, Río Amazonas, braid off right bank of main channel ca. $6 \mathrm{~km}$ northeast (downstream) of mouth of Río Nanay,03³9’37.3”S 73¹2’16.7”W, 17 Aug 2015, K. Evans. ANSP 200511, 3, 169-205 mm LEA, Peru, Loreto, Río Amazonas, 0342'79'S 073¹3'95.2”W, 26 Aug 2016, K. Evans.

\section{Sternarchella schotti (Steindachner, 1868b)}

Fig. 24, Tab. 9

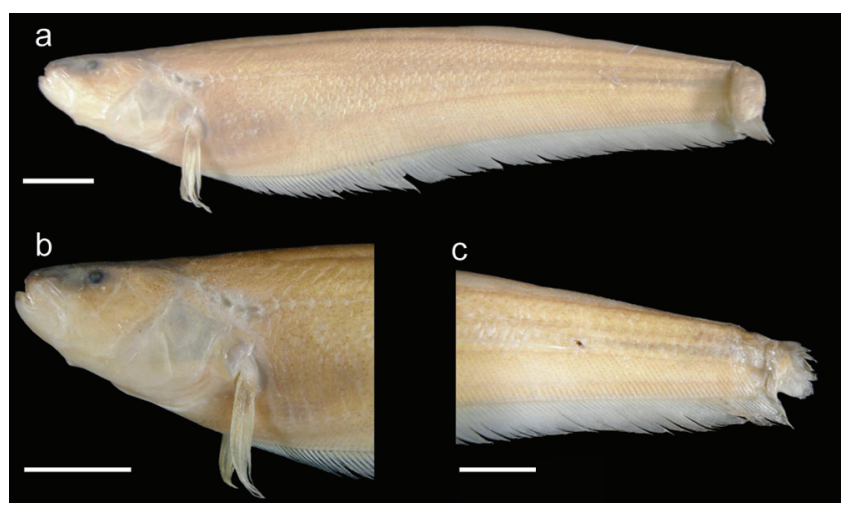

Fig. 24. Sternarchella schotti in lateral view (INPA 15801). a. Lateral view of the body. b. Lateral view of the head. c. Lateral view of the caudal region showing a single row of intermuscular bones in the caudal peduncle and a discontinuous caudal peduncle membrane. Scale bars $=1.5 \mathrm{~cm}$.

Tab. 9. Morphometrics and meristic measurements for Sternarchella schotti.

\begin{tabular}{lcccc}
\hline Characters & Minimum & Maximum & Mean & $\mathrm{n}$ \\
\hline LEA (mm) & 117.0 & 165.0 & 143.4 & 4 \\
AFL & 96.0 & 131.0 & 116.8 & 4 \\
HD1 & 10.1 & 14.4 & 12.4 & 4 \\
HD2 & 14.3 & 22.6 & 18.6 & 4 \\
HL & 21.2 & 30.5 & 26.4 & 4 \\
PR & 6.6 & 10.0 & 8.1 & 4 \\
PO & 13.6 & 14.8 & 16.6 & 4 \\
ED & 1.9 & 1.8 & 2.1 & 4 \\
IO & 2.9 & 4.7 & 3.8 & 4 \\
HW & 7.7 & 9.9 & 10.6 & 4 \\
MW & 3.4 & 3.4 & 4.5 & 4 \\
PA & 7.5 & 6.7 & 12.3 & 4 \\
CPD & 3.1 & 4.5 & 4.6 & 3 \\
CPL & 2.8 & 18.0 & 2.8 & 1 \\
AFR & 145 & 191 & 166 & 4 \\
Unbranched AFR & 21 & 22 & 25 & 4 \\
Pre-caudal vertebrae & 15 & 16 & - & 4 \\
PR\% & Percent HL & & & \\
PO\% & 29.5 & 32.8 & 30.8 & 4 \\
ED\% & 59.0 & 67.1 & 63.2 & 4 \\
IO\% & 7.2 & 9.6 & 8.1 & 4 \\
HW\% & 12.2 & 16.7 & 14.4 & 4 \\
MW\% & 36.3 & 43.9 & 39.5 & 4 \\
PA\% & 16.0 & 17.7 & 17.0 & 4 \\
CPD\% & 35.4 & 49.8 & 45.9 & 4 \\
CPL\% & 13.1 & 23.9 & 17.5 & 3 \\
CPD/CPL & 11.8 & 11.8 & 11.8 & 1 \\
HL/LEA & 110.7 & 110.7 & 110.7 & 1 \\
LEA/CPD & 17.1 & 19.8 & 18.4 & 4 \\
PR/PO & 2.2 & 4.4 & 3.2 & 3 \\
\hline
\end{tabular}


Sternarchus schotti Steindachner, 1868b: 252, tab. 1, figs. 1-2 [type locality: Brazil, Amazonas, near mouth of río Negro Manaus]. Sternarchus capanemae Steindachner, 1868a: 176, fig. 1 [type locality: Brazil].

Porotergus terminalis Eigenmann \& Allen, 1942:324 [type locality: Peru, río Amazonas, Iquitos].

Sternarchella schotti. -Crampton, Albert, 2006:676, fig. 23.11 [Brazil, Amazonas, Tefé]. -Crampton, 2007:311, fig. 11.6 [type locality: Brazil, Amazonas, Tefé]. -Lundberg et al., 2013:163, fig. 5 [Brazil, rio Amazonas above rio Trombetas].

Diagnosis. Sternarchella schotti is readily distinguished from congeners by the presence of a large eye, ED, 7-10\% HL ( vs. $6-9 \%$ HL in $S$. calhamazon, $S$. duccis, S. orinoco, $S$. orthos, $S$. rex, S. raptor, and S. sima) (shared with S. patriciae), the presence of an ossified third basibranchial, the presence of four to five curved displaced hemal spines, and the presence of an elongate swim bladder that extends beyond the posterior limit of the body cavity.

Description. Pectoral fin size small, less than $80 \%$ HL. PA $\%$ moderate, $46-49 \%$ HL. Head width narrow, distance between lateral margins $36-44 \%$ HL. Preorbital (snout) length moderate, 30-33\% HL. Postorbital distance small, 59-67\% HL small. Eye diameter large, $7-10 \% \mathrm{HL}$ or more. Interorbital distance small, 12-17\% HL. Mouth narrow, distance between ricti $16-18 \%$ HL. Body depth less than HL. Body translucent in living specimens, yellow or pink hue in living specimens. Scales absent on posterolateral portion of body. Scales large in size with 5-8 present above lateral line at mid-body. Scales dorsal to lateral line rhomboid at mid-body. Rictus extends to a vertical with mental symphysis, gape very small, less than twice eye diameter. Rictus extends to a vertical with mental symphysis. Oral aperture terminal, upper and lower jaws equal in length. Body cavity long; 15-16 pre-caudal vertebrae present. Proximal surface of first displaced hemal spine narrower then descending blade. Four to five curved displaced hemal spines. Swim bladder elongate past posterior limit of body cavity. Anal-fin pterygiophore length longer than hemal spines. Anal-fin proximal long, equal or longer than hemal spine. One row of bones in caudal peduncle visible externally. Caudal peduncle shallow depth 13-24\% HL. Dark spot on caudal peduncle absent. No apparent connective tissue between anal-fin base and caudal peduncle. Caudal peduncle length less than HL. Premaxilla size large, lateral margin of premaxilla longer than lateral margin of maxilla. Premaxilla triangular in ventral view. Three rows of teeth present on premaxilla. Anterior hook of maxilla absent, anterior process broad and triangular with a continuous ventral margin with descending blade. Anterior process of maxilla extending as a shelf of bone less than one-third length of descending blade. Ventral margin of maxillary blade curves evenly towards its distal tip. Descending blade maxilla thin, evenly curves. Two rows of teeth present on dentary. Dentary longer than deep, oral margin of dentary longer than length of angular articular. Dorsal margin of dentary slightly concave in lateral view.
Posterior margin of dentary curves gradually to descending limb. Endopterygoid process small, not contacting frontal. Endopterygoid process extends vertically at or near a $90^{\circ}$ angle with dorsal surface of endopterygoid. Endopterygoid process slender with a narrow tip. Hyomandibula short, its width half its length. Dorsal margin of opercle concave. Opercle broad, width over half depth. Base of gill rakers contacting gill arch. Anterior limb of cleithrum length greater than cleithrum ascending limb length. Post-temporal fused with supracleithrum in mature specimens. Ventral ethmoid large and robust with a large fan-shaped lateral process. Dorso-anterior portion of mesethmoid straight. Anterior tip of mesethmoid scyphate on dorsal surface. Anterior fontanel longer than posterior fontanel. Lateral ethmoid very robust and large, may contact ventral portion on frontals, hour-glass shaped with most narrow portion at mid-length. Orbitosphenoid broad, well ossified in median nasal septum with ventral margin longer than dorsal margin. Dorso-medial portion of orbitosphenoids in contact (visible through anterior fontanel in dorsal view). Process originating from ventral portion of most anterior part of pterosphenoid present, sometimes contacting parasphenoid, anterior ventral margin of pterosphenoid similar to posterior ventral margin of orbitosphenoids. Small, lateral margins of parasphenoid not extending to a horizontal with trigeminal foramen. Parasphenoid ventral margin straight or slightly curved, narrow, just lateral to supraoccipital Parietal ridges are very large and pronounced. Absence of thorny projections at border of parietals and supraoccipital. Dorsal margin of supraoccipital crest exceed dorsal margin of parietals. Supraoccipital crest extends to a dorsal distal tip. Internal carotid foramen reduced. Ventral surface of basioccipital smooth. Anterior extension of infraorbital canal shorter than width of canal pore, anterior canal pore of infraorbital near first infraorbital. Supraorbital canal fused to frontal. Mandibular canal size small. Mandibular canal ossicles form long slender tubes. Supratemporal laterosensory canal curved at a sharp angle on surface of parietal, extending posterior onto epaxial surface of body, terminal canal pore oriented posteriorly, epidermis overlying supratemporal canal depigmented.

Gill rakers long with ossified distal tips. Dorsal surface of basihyal flat; small ridge may be present posteriorly. Second basibranchial fan-shaped, extending to long narrow end. Third basibranchial ossified. Twelve or less teeth present on pharyngobranchial. Eight or more teeth present on sixth hypobranchial. Medial surface of fourth hypobranchial with a process or bridge extending to meet contralateral process on midline. Urohyal blade unossified. First hypohyal bell-or cylinder shaped.

Coloration in alcohol. Yellowish brown color, with a darker brown stripe confined to the dorsum running the length of the body, with striations demarcating the ribs at the body cavity (Fig. 12b).

Sexual dimorphism. Not known, insufficient mature male and female specimens to determine. 
Distribution and habitat. Distributed throughout the deep channels of the Amazon and Orinoco basins. Ivanyisky, Albert (2014) described S. schotti as being restricted to the Amazon basin (Fig. 17). However, a single juvenile specimen of $S$. schotti was found inhabiting the río Meta in Colombia, suggesting that $S$. schotti may have a wider range than originally hypothesized.

Remarks. Sternarchella schotti is readily differentiated from sympatric congeners by the presence of a swim-bladder that extends beyond the posterior margin of the body cavity, visible when held up to a strong light source.

Taxonomic status of Sternarchella terminalis. Sternarchella terminalis (Eigenmann \& Allen, 1942) was originally described as Porotergus terminalis and reassigned to the genus Sternarchella by Mago-Leccia (1994). However, closer examination of the holotype of $S$. terminalis (IU or CAS 15994), collected near Iquitos, Peru, shows that it possesses the larger eye diameter and distinct configuration of displaced hemal spines that are diagnostic of $S$. schotti (Steindachner, 1868b; fig. 5). We therefore conclude that S. terminalis (Eigenmann \& Allen) is a junior synonym of S. schotti (Steindachner, 1868b). A species with a similar external phenotype, also present in the Amazon and Orinoco basins, has been incorrectly referred to as $S$. terminalis in the Amazon previously (Ivanyisky, Albert, 2014; Lundberg et al., 2013), and was described as S. orthos Mago-Leccia (1994) from the Orinoco basin. Despite measurable morphometric variation among populations of this species in several parts of the Amazon and Orinoco basins, we were unable to discover diagnostic differences among these populations, and here treat the species as $S$. orthos with a broad geographic range and morphometric variation. A note on the taxonomic status of Sternarchus capanemae was published in Lundberg et al. (2013); here the authors recognize Sternarchus capanemae as a junior synonym of $S$. schotti.

Material examined. Holotype. Sternarchus schotti: NMW 65335, 1, Brazil, Manaus, mouth of río Negro, F. Steindachner. Nontypes. Sternarchella schotti: ANSP 199195, 4, 117-165 mm LEA, Brazil, río Amazonas above río Trombetas. BMNH 1998.3.17.54, 1, 195 mm TL, Brazil, Mamirauá Lake System, Paraná do Apara:

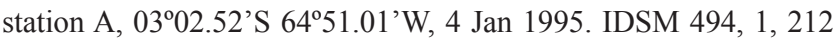
mm TL, Brazil, río Solimões, south bank of Ilha Içé, $03^{\circ} 16.08^{\prime} \mathrm{S}$ 64²41.35’W, 3 Sep 1999. INPA 15801, 5, 176-241 mm, Rio Japurá, West bank, between Boca do Lago Mamirauá and Boca do Paraná do Jaquiri, $03^{\circ} 07.58^{\prime}$ 'S $64^{\circ} 47.30^{\prime} \mathrm{W}, 19$ Jan 99. INPA 18191, 4, 231-245 mm TL, Brazil, Mamirauá Lake System, Paraná Maiana station A, 03 $06.74^{\prime} \mathrm{S} 64^{\circ} 47.53^{\prime} \mathrm{W}$, 26 Jan 1999. INPA 18192, 3, 212-233 mm TL, Brazil, río Japurá-Solimões Confluence, Praia Caborini, 030․ 09 'S $64^{\circ} 47.06^{\prime} \mathrm{W}, 24$ Feb 2000. INPA 18260, 1, 210 mm TL, Brazil, río Japurá, West bank, between Boca do Lago

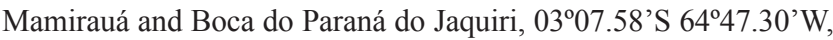
9 Feb 1999. INPA 182161, 1, 197 mm TL, Brazil, río Tefé, Toco Preto, $03^{\circ} 47.31^{\prime} \mathrm{S} 64^{\circ} 59.91^{\prime} \mathrm{W}, 23$ October 1999. INPA 18262,
1, 159 mm TL, Brazil, Mamirauá Lake System, Paraná Maiana station B, $03^{\circ} 04.83^{\prime} \mathrm{S} 64^{\circ} 47.30^{\prime} \mathrm{W}, 11$ Jan 2000 . INPA 18263 , 3, 128-140 mm TL, Brazil, río Japurá, West bank at Boca do Lago Mamirauá, $03^{\circ} 07.13^{\prime}$ 'S 644․ $30^{\prime} \mathrm{W}, 7$ Dec 1999. INPA 18264, 2, 171-187 mm TL, Brazil, río Japurá at mouth of Lago Caxinguba, 0306.17'S 64º5.84'W, 3 Feb 1999. MCP 33371, 1, 199 mm TL, Brazil, río Japurá, West bank, between Boca do Lago Mamirauá

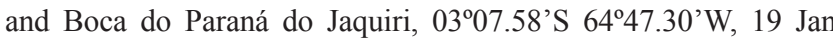
1999. MCP 33372, 2, 217-217 mm TL, Brazil, Mamirauá Lake System, Paraná Maiana station A, $03^{\circ} 06.74^{\prime}$ 'S $64^{\circ} 47.53^{\prime} \mathrm{W}, 28$ Jan 1999. MCP 33373, 3, 211-222 mm TL, Brazil, río Japurá at mouth of Lago Caxinguba, $03^{\circ} 06.17^{\prime} \mathrm{S} 64^{\circ} 45.84$ 'W, 3 Feb 1999. MCP 33389, 2, 243-244 mm TL, Brazil, río Japurá-Solimões Confluence, Praia Caborini, 0309.14'S 64²7.06'W, Jan 1999. MCP 49424, 1, $116 \mathrm{~mm}$ TL, Brazil, Ponta Mucuri, río Solimões, 030'28"S 6452'00”'W, 28 Aug 1993. MCP 49425, 1, 114 mm TL, Brazil, Mamirauá Lake System, Lago Promessa, 0304'23”'S 6446 '52”W, 19 May 1999. MCP 49426, 1, 173 mm TL, Brazil, río Japurá, West bank, between Boca do Lago Mamirauá and Boca do Paraná do Jaquiri, 0307'35”'S 6447'18”W, 19 Jan 1999. MCP 49427, 1, 132 mm TL, Brazil, río Japurá, West bank at Boca do Lago Mamirauá, 0307'36"S 6446’15”W, 7 Dec 1999. MCP 49428, 1, 210mm TL, Brazil, río Solimões, South bank of Ilha Içé, $03^{\circ} 16^{\prime} 05^{\prime \prime S}$ 64.41'21"W, 30 Jan 2001. MCP 49429, 10, 150-225 mm TL, Brazil, río Japurá-Solimões Confluence, Praia Caborini, 0309'08"S 6447’04”'W, 10 Feb 2001. MCP 49430, 1, 166 mm TL, Brazil, río Solimões, South bank of Ilha Içé, $03^{\circ} 16^{\prime} 36^{\prime \prime}$ 'S $64^{\circ} 41^{\prime} 01^{\prime \prime W}, 13$ Jan 2001. MCP 49431, 2, 163-249 mm TL, Brazil, río Solimões near

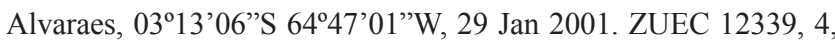
179-197 mm TL, Brazil, Mamirauá Lake System, Paraná Maiana station A, $03^{\circ} 06.74^{\prime} \mathrm{S} 64^{\circ} 47.53^{\prime} \mathrm{W}, 2$ Mar 1999. Colombia: UF 26079, 1, Colombia, Meta, río Meta, small temporary pond $15 \mathrm{~km}$ east of Puerto Gaitán. UF 116570, 1, (C\&S), Peru, Maynas, Loreto, río Amazonas, locality unknown. "Porotergus terminalis": CAS 52833, 1, 234 LEA, Peru, río Amazonas, Iquitos.

\section{Sternarchella sima Starks, 1913}

Fig. 25, Tab. 10

Sternarchella sima Starks, 1913:22, plate 4 [type locality: Brazil, Pará, Belém market].

Diagnosis. Sternarchella sima is readily distinguished from congeners by the presence of a short snout (preorbital length $18-28 \%$ HL) (vs. 29-36\% HL in S. duccis, S. orinoco, S. orthos, S. patriciae, S. raptor, S. rex, and S. schotti) (shared with $S$. calhamazon), the possession of a large interorbital distance (19-25\% HL) (vs. 11-19 \%HL in S. calhamazon, S. duccis, S. orinoco, $S$. orthos, $S$. patriciae, $S$. raptor, and $S$. schotti) (shared with $S$. rex), the possession of a deep body (body depth equal to or greater than HL (vs. shallow body depth, less than HL in $S$. calhamazon, S. duccis, S. orinoco, S. orthos, S. patriciae, S. raptor, S. schotti) (shared with $S$. rex), and the presence of gill rakers in which the base does not contact the gill arch (vs. contacting in all other Sternarchella species). 


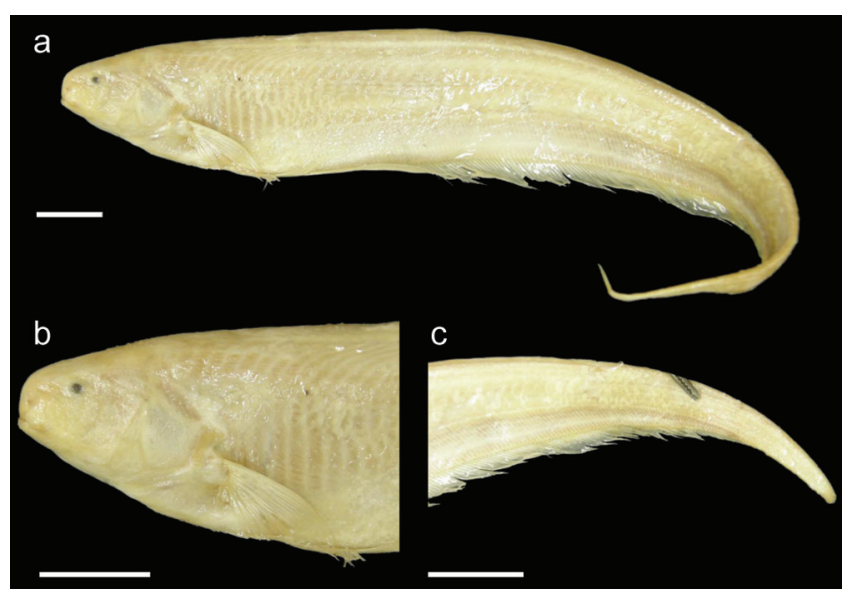

Fig. 25. Sternarchella sima paratype (AMNH 3864). a. Lateral view of the body, b. Lateral view of the head, c. Lateral view of the caudal region showing a single row of intermuscular bones in the caudal peduncle and a discontinuous caudal peduncle membrane. Scale bars $=1 \mathrm{~cm}$.

Tab. 10. Morphometrics and meristic measurements for Sternarchella sima.

\begin{tabular}{lcccc}
\hline Characters & Minimum & Maximum & Mean & $\mathrm{n}$ \\
\hline LEA (mm) & 128.0 & 184.0 & 145.8 & 5 \\
AFL & 106.0 & 138.0 & 121.0 & 5 \\
HD1 & 7.8 & 9.6 & 8.8 & 5 \\
HD2 & 13.8 & 15.9 & 15.0 & 5 \\
HL & 17.7 & 21.1 & 19.6 & 5 \\
PR & 3.6 & 5.3 & 4.7 & 5 \\
PO & 11.7 & 14.8 & 13.5 & 5 \\
ED & 1.2 & 1.8 & 1.4 & 5 \\
IO & 3.6 & 4.7 & 4.4 & 5 \\
HW & 7.6 & 9.9 & 8.7 & 5 \\
MW & 2.4 & 3.4 & 2.9 & 5 \\
PA & 4.9 & 6.7 & 5.9 & 5 \\
CPD & 2.3 & 4.5 & 3.0 & 5 \\
CPL & 3.0 & 18.0 & 9.2 & 5 \\
AFR & 183 & 191 & 187 & 4 \\
Unbranched AFR & 15 & 22 & 25 & 4 \\
Pre-caudal vertebrae & 15 & 15 & - & 4 \\
& Percent HL & & & \\
PR\% & 18.3 & 27.6 & 24.2 & 5 \\
PO\% & 64.0 & 75.1 & 69.2 & 5 \\
ED\% & 5.7 & 9.1 & 7.3 & 5 \\
IO\% & 1.2 & 3.1 & 2.0 & 5 \\
HW\% & 18.7 & 24.9 & 22.3 & 5 \\
MW\% & 39.6 & 48.7 & 44.7 & 5 \\
PA\% & 11.9 & 16.1 & 14.6 & 5 \\
CPD\% & 24.2 & 35.6 & 30.5 & 5 \\
CPL\% & 11.7 & 22.4 & 15.1 & 5 \\
CPD/CPL & 14.2 & 93.7 & 47.3 & 5 \\
HL/LEA & 14.4 & 90.0 & 53.8 & 5 \\
LEA/CPD & 10.7 & 15.2 & 13.6 & 5 \\
PR/PO & & & & \\
\hline & & 35.2 & 5 \\
\hline
\end{tabular}

Description. A medium-sized species, to $189 \mathrm{~mm}$ LEA. Pectoral fin size large, $80 \%$ HL or greater. PA $\%$ small, 24-36\% HL. Head width narrow, distance between lateral margins 40-49\% HL. Preorbital (snout) length small, 18$28 \%$ HL. Postorbital distance large, $64-75 \%$ HL. Eye diameter small, 6-9\% HL. Interorbital distance large, 19$25 \%$ HL. Mouth narrow, distance between ricti $12-16 \%$ HL. Body depth equal or greater than HL. Scales absent on posterolateral portion of body. Scales large in size with 5-8 present above lateral line at mid-body. Scales dorsal to lateral line rhomboid at mid-body. Rictus extends to a vertical with mental symphysis, gape very small, less than twice eye diameter. Oral aperture sub-terminal, upper jaw extends anteriorly to lower jaw. Body cavity long, 15 precaudal vertebrae. Proximal surface of first displaced hemal spine narrower then descending blade. 1-2 displaced hemal spines. Swim bladder not extending posterior to body cavity. Anal-fin pterygiophore length equal to or shorter than hemal spines. Anal-fin proximal short, length shorter than hemal spine. One row of bones in caudal peduncle visible externally. Caudal peduncle shallow less than 30\% HL Dark spot on caudal peduncle absent. No apparent connective tissue between anal-fin base and caudal peduncle. Caudal peduncle length short, less than HL. Premaxilla large, lateral margin of premaxilla longer than lateral margin of maxilla. Premaxilla square in ventral view. Four rows of teeth present on premaxilla. Anterior hook of maxilla absent, anterior process broad and triangular with a continuous ventral margin with descending blade. Anterior process of maxilla extending as a shelf of bone less than one-third length of descending blade. Ventral margin of maxillary blade curved evenly towards its distal tip. Descending blade maxilla thin, evenly curved. Three to four rows of teeth present on dentary. Dentary longer than deep, oral margin of dentary longer than length of angular articular. Dorsal margin of dentary slightly concave in lateral view. Posterior margin of dentary curved gradually to descending limb. Endopterygoid large, contacting frontal. Angle of endopterygoid process with dorsal margin of endopterygoid oblique (greater than $90^{\circ}$ with dorsal surface of endopterygoid). Endopterygoid process slender with a narrow tip. Hyomandibula short, its width half its length. Dorsal margin of opercle concave. Opercle broad, width over half depth. Anterior limb of cleithrum length greater than cleithrum ascending limb length. Post-temporal fused with supracleithrum in mature specimens. Ventral ethmoid size large and robust with a large fan-shaped lateral process. Dorso-anterior portion of mesethmoid strongly curved from anterior tip to frontal boundary. Anterior tip of mesethmoid convex and rounded. Anterior fontanel longer than posterior fontanel. Lateral ethmoid large hour-glass shaped, narrowest portion at mid-length. Orbitosphenoid broad, well ossified in median nasal septum with ventral margin longer than dorsal margin. Dorso-medial portion of orbitosphenoids in contact (visible through anterior fontanel in dorsal view). Absence of ventral process of pterosphenoid, anterior ventral margin of pterosphenoid similar to posterior 
ventral margin of orbitosphenoids. Small, lateral margins of parasphenoid not extending to a horizontal with trigeminal foramen. Parasphenoid ventral margin straight or slightly curved. Distance between parietal ridges short, just lateral to supraoccipital, parietal ridges very large and pronounced. No crown of thorny projections present at border of parietals and supraoccipital. Dorsal margin of supraoccipital crest extends beyond dorsal margin of parietals. Supraoccipital crest extends to a dorsal distal tip. Internal carotid foramen reduced. Ventral surface of basioccipital smooth. Anterior extension of infraorbital canal shorter than width of canal pore, anterior canal pore of infraorbital near first infraorbital. Supraorbital canal fused to frontal. Mandibular canal size small. Mandibular canal ossicles form long slender tubes. Supratemporal laterosensory canal curved at a sharp angle on surface of parietal, extending posterior onto epaxial surface of body, terminal canal pore oriented posteriorly, epidermis overlying supratemporal canal depigmented. Base of gill rakers not contacting gill arch. Gill rakers long, with ossified distal tips. Dorsal surface of basihyal convex, forming a robust ridge posteriorly. Second basibranchial triangular with short stem, length of descending rod less than dorsal margin. Third basibranchial unossified. Fourteen or more teeth present on pharyngobranchial. Eight or more teeth present on sixth hypobranchial. Medial surface of fourth hypobranchial with a process or bridge extending to meet contralateral process on midline. Urohyal blade unossified. First hypohyal triangular, base longer than any other margin of bone.

Coloration in alcohol. Yellowish brown color, with a darker brown stripe confined to the dorsum running the length of the body, with striations demarcating the ribs at the body cavity.

Sexual dimorphism. Insufficient specimens are available to ascertain differences between males and females. However, Mago-Leccia (1994) reported that mature female specimens of $S$. sima have wider heads in the lateral dimension than males of comparable sizes.

Distribution and habitat. Known from the eastern portion of the lowland Amazon basin, with most specimens known from near its mouth (Fig. 19).

Remarks. Sternarchella sima superficially resembles, $S$. orinoco in possessing a sub-terminal mouth, three rows of teeth on the pre-maxilla and dentary, and ventral flexion of the mesethmoid region. However, S. sima is a smaller species, reaching $189 \mathrm{~mm}$ LEA (vs. $221 \mathrm{~mm}$ in $S$. orinoco), with a slightly shorter face, pre-orbital length $18-28 \%$ HL (vs. 26$32 \% \mathrm{HL}$ in $\mathrm{S}$. orinoco). Two specimens catalogued as S. sima from the western Amazon are not recognized in this species herein. The paratype of $S$. sima designated by Starks (1913) described the specimen as having 193 anal-fin rays, here we describe that specimen as possessing 191 anal-fin rays.
Material examined. Paratype. Sternarchella sima: AMNH 3864, 1, Brazil, Pará, Belém Market, E. C. Starks. Non-types. Sternarchella sima: ANSP 192108, 1, 146 mm LEA, Brazil, rio Pará above rio Tocantins $83.3 \mathrm{~km}$ upriver from town of Abaetetuba, $9.1 \mathrm{~km}$ downriver from Boa Vista. USNM 373114, 2, 132-139 mm LEA, Brazil, río Amazonas, $15 \mathrm{~km}$ above Breves. ANSP 192107 (3 C\&S), Brazil, Pará, rio Jari downstream of Monte Dourado, upstream of Bom Jardim. INPA 48443, 1, Brazil, Pará, Amazon above rio Tapajós.

\section{Acknowledgments}

We thank Jonathan Baskin, Maxwell Bernt, Otto Castillo, Tiago Carvalho, Prosanta Chakrabarty, Michael Goulding, John Lundberg, Franco Provenzano, Donald Taphorn, Brandon Waltz, and Angela Zanata for access to specimens collected in the field. We also thank Kyle Luckenbill (ANSP), Jeffry Smith (USNM), Caleb McMahan (FMNH), Hernán Ortega (MUSM), Lucia Rapp Py-Daniel (INPA) and Anja Palandacic (NMW) for specimen loans and radiographs. Alex Orfinger captured specimens of $S$. rex from Peru and assisted with radiography of $S$. rex specimens. Jonas Alves de Oliveira and Instituto Mamirauá provided field support to WGRC in Brazil. Vanessa Correa-Roldan provided field support to WGRC in Peru. Field work and specimen exports in Brazil were authorized to JSA and WGRC via Expedição Científica-CNPq, the Instituto Brasileiro do Meio Ambiente e dos Recursos Naturais Renováveis, and a Material Transfer Agreement with Museu de Ciência e Tecnologia - Pontifícia Universidade Católica do Río Grande do Sul. Field work and specimen exports from Peru were authorized by permits from the Direction Regional de la Produción Regional de Loreto to JSA and WGRC. We also thank Victor Tagliacollo and Dagoberto Venera-Ponton for help with the manuscript. This work was supported by the US NSF 0614334, 0741450 and 1354511 to JSA, and US NSF 1146374 and 0614334 Conselho Nacional de Desenvolvimento Científico e Tecnológico $(\mathrm{CNPq})$, Brazil, and the Ministério de Ciência e Tecnologia, Brazil, to WGRC.

\section{References}

Alberch P, Gould SJ, Oster GF, Wake DB. Size and shape in ontogeny and phylogeny. Paleobiology. 1979; 5(3):296-317.

Albert JS. Species diversity and phylogenetic systematics of American knifefishes (Gymnotiformes, Teleostei). Division of Ichthyology, Museum of Zoology, University of Michigan. 2001.

Albert JS. Fishes of the Fitzcarrald, Peruvian Amazon: Raleigh: Lulu Press; 2012.

Albert J, Crampton WGR. Electroreception and electrogenesis. In: Evans DH, Claiborne JB, editors. The physiology of fishes. Boca Raton: CRC Press; 2005. p.429-470.

Albert JS, Crampton WGR. Pariosternarchus amazonensis: a new genus and species of Neotropical electric fish (Gymnotiformes: Apteronotidae) from the Amazon River. Ichthyol Explor Freshw. 2006; 17(3):267-74. 
Albert JS, Crampton WGR. A new species of electric knife fish, genus Compsaraia (Gymnotiformes: Apteronotidae) from the Amazon River, with extreme sexual dimorphism in snout and jaw length. Syst Biodivers. 2009; 7(1):81-92.

Albert JS, Reis RE, editors. Historical biogeography of Neotropical freshwater fishes. Berkeley: University of California Press; 2011.

Bremer K. Branch support and tree stability. Cladistics. 1994; 10(3):295-304.

Crampton WGR. An ecological perspective on diversity and distributions. In: Albert JS, Reis R, editors. Historical biogeography of neotropical freshwater fishes. California: University of California Press; 2011. p.165-189.

Crampton WGR. Diversity and adaptation in deep channel Neotropical electric fishes. In: Scbert P, Onyango DW, Kapoor BG, editors. Fish life in special environments. New Hampshire: Science Publishers, Inc.; 2007. p.283-339.

Crampton WGR, Albert JS. Evolution of electric signal diversity in gymnotiform fishes. Phylogenetic systematics, ecology and biogeography. In: Ladich F, Collin SP, Moller P, Kapoor BG, editors. Communication in fishes. Enfield: Science Publishers; 2006. p.647-96; 718-731.

Crampton WGR, Cella-Ribeiro A. Capitulo 44 Apteronotidae. In: de Queiroz LJ, Torrente-Vilara G, Ohara WM, Pires THS, Zuanon J, and Doria CRC, editors. Peixes do Rio Madeira. Vol. 3. São Paulo, Brazil: Santo Antônio Energia; 2013. p.256-289.

Eigenmann CH, Allen WR. Fishes of Western South America: 1. The Intercordilleran and Amazonian Lowlands of Peru. 2. The High Pampas of Peru, Bolivia and Northern Chile; With a Revision of the Peruvian Gymnotidae and of the Genus Orestias. Kentucky: University of Kentucky Press; 1942.

Evans KM, Waltz BT, Tagliacollo VA, Sidlauskas BL, Albert JS. Fluctuations in evolutionary integration allow for big brains and disparate faces. Sci Rep. 2017a; 7:40431.

Evans KM, Waltz BT, Tagliacollo VA, Chakrabarty P, Albert JS. Why the short face? Developmental disintegration of the neurocranium drives convergent evolution in Neotropical electric fishes. Ecol Evol. 2017b; 7(6):1783-1801.

Farias IP, Torrico JP, García-Dávila C, Santos MCF, Hrbek T, Renno J-F. Are rapids a barrier for floodplain fishes of the Amazon basin? A demographic study of the keystone floodplain species Colossoma macropomum (Teleostei: Characiformes). Mol Phylogenet Evol. 2010; 56(3):1129-35.

Ferraris CJ, Jr., de Santana CD, Vari RP. Checklist of Gymnotiformes (Osteichthyes: Ostariophysi) and catalogue of primary types. Neotrop Ichthyol. 2017; 15(1):e160067.

Goloboff PA, Farris JS, Nixon KC. TNT, a free program for phylogenetic analysis. Cladistics. 2008; 24(5):774-86.

Ivanyisky SJ, Albert JS. Systematics and biogeography of Sternarchellini (Gymnotiformes: Apteronotidae): Diversification of electric fishes in large Amazonian rivers. Neotrop Ichthyol. 2014; 12(3):564-84.

Johnson JH, Dropkin DS, Warkentine BE, Rachlin JW, Andrews WD. Food habits of Atlantic sturgeon off the central New Jersey coast. T Am Fish Soc. 1997; 126(1):166-70.

Klingenberg CP. MorphoJ: an integrated software package for geometric morphometrics. Mol Ecol Resources. 2011; 11(2):353-57.

Lowry D, Wintzer AP, Matott MP, Whitenack LB, Huber DR, Dean M, Motta PJ. Aerial and aquatic feeding in the silver arawana, Osteoglossum bicirrhosum. Environ Biol Fishes. 2005; 73(4):453-62.
Lundberg JG, Fernandes CC, Albert JS, Garcia M. Magosternarchus, a new genus with two new species of electric fishes (Gymnotiformes: Apteronotidae) from the Amazon River basin, South America. Copeia. 1996; 1996 (3):657-70.

Lundberg JG, Fernandes CC, Campos-Da-Paz R, Sullivan JP. Sternarchella calhamazon n. sp., the Amazon's most abundant species of apteronotid electric fish, with a note on the taxonomic status of Sternarchus capanemae Steindachner, 1868 (Gymnotiformes, Apteronotidae). Proc Acad Nat Sci Philadelphia. 2013; 162(1):157-73.

Mago-Leccia F. Electric fishes of the continental waters of America: classification and catalogue of the electric fishes of the order Gymnotiformes (Teleostei: Ostariophysi), with descriptions of new genera and species. Caracas: Fundacion para Desarrollo de las Ciencias Fiscias, Matematicas y Naturales; 1994.

Montaña CG, Winemiller KO. Evolutionary convergence in Neotropical cichlids and Nearctic centrarchids: evidence from morphology, diet, and stable isotope analysis. Biol J Linnean Soc. 2013; 109(1):146-64.

Ochoa LE, Pereira LHG, Costa Silva GJ, Roxo FF, Batista JS, Formiga K et al. Genetic structure and historical diversification of catfish Brachyplatystoma platynemum (Siluriformes: Pimelodidae) in the Amazon basin with implications for its conservation. Ecol Evol. 2015; 5(10):2005-20.

Pimentel RA, Riggins R. The nature of cladistic data. Cladistics. 1987; 3(3):201-09.

Rohlf FJ, "tpsDig, version 2.10." Department of Ecology and Evolution, State University of New York, Stony Brook. 2006.

Rohlf FJ, "tps Util, v. 1.40." Stony Brook, NY: Department of Ecology \& Evolution, SUNY Stony Brook. 2008.

Rüber L, Adams DC. Evolutionary convergence of body shape and trophic morphology in cichlids from Lake Tanganyika. J Evol Biol. 2001; 14(2):325-32.

Sazima I. Scale-eating in characoids and other fishes. Environ Biol Fishes. 1983; 9(2):87-101.

Starks EC. The fishes of the Stanford Expedition to Brazil. Palo Alto: Stanford University Publications; 1913.

Tagliacollo VA, Bernt MJ, Craig JM, Oliveira C, Albert JS. Modelbased total evidence phylogeny of Neotropical electric knife fishes (Teleostei, Gymnotiformes). Mol Phylogenet Evol. 2016; 95:20-33.

Taylor WR, Van Dyke GC. Revised procedures for staining and clearing small fishes and other vertebrates for bone and cartilage study. Cybium. 1985; 9(2):107-19.

Torrente-Vilara G, Zuanon J, Leprieur F, Oberdorff T, Tedesco PA. Effects of natural rapids and waterfalls on fish assemblage structure in the Madeira River (Amazon Basin). Ecol Freshw Fish. 2011; 20(4):588-97.

Weitzman SH. Osteology and evolutionary relationships of the Sternoptychidae, with a new classification of stomiatoid families. Bull Am Mus Nat Hist. 1974; 153(3):139-478.

Submitted July 21, 2016

Accepted March 9, 2017 by Fernando Carvalho 
